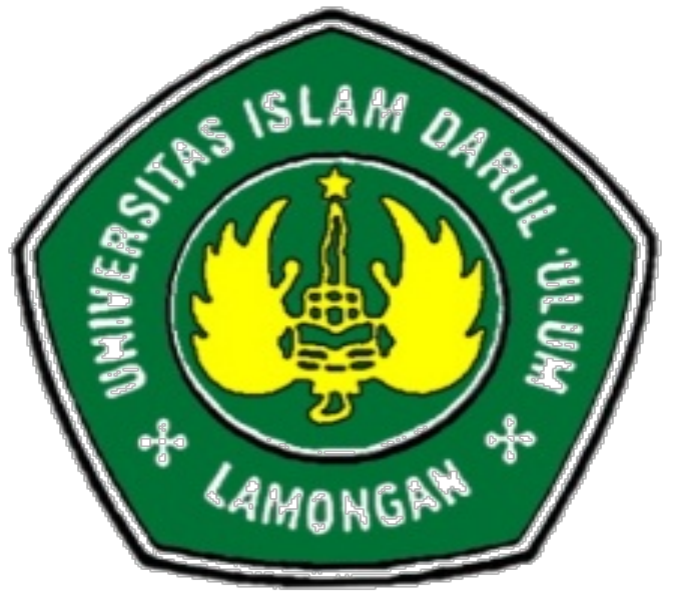

\title{
Hand Out Teori - Teori Politik
}
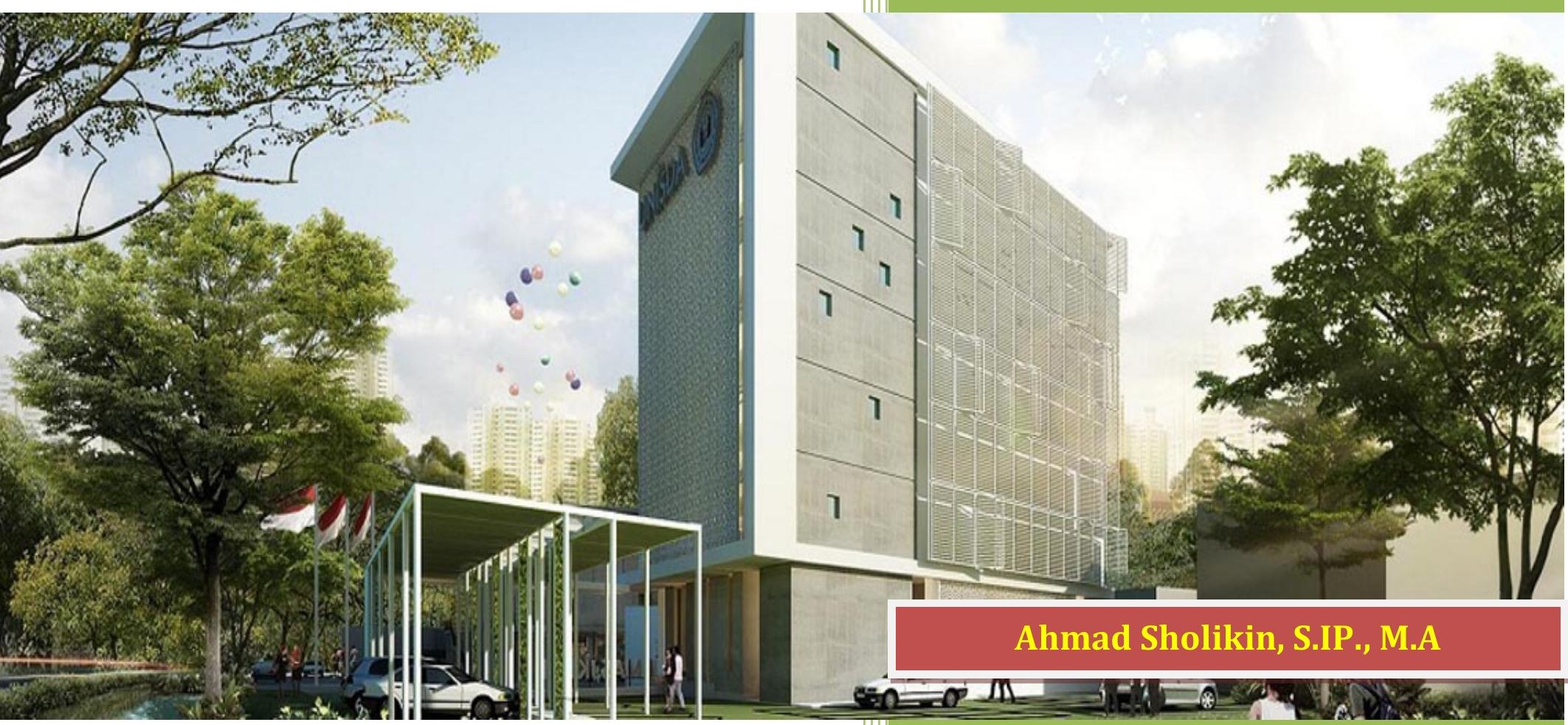

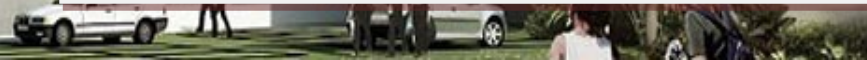

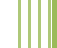

Bahan Ajar Mata Kuliah Teori-Teori Politik Ilmu Politik dan Ilmu Pemerintahan

Fakultas Ilmu Sosial dan Ilmu Politik Universitas Islam Darul 'Ulum Lamongan $2016 / 2017$ 


\section{BAB I \\ PENDAHULUAN}

\section{Konsep-konsep Politik}

Sejak awal hingga perkembangan terakhir terdapat sekurangkurangnya lima pandangan mengenai politik. Pertama, politik ialah usahausaha yang ditempuh oleh warga negara untuk membicarakan dan mewujudkan kebaikan bersama. Kedua, politik ialah segala hal yang berkaitan dengan penyelenggaraan negara dan pemerintahan. Ketiga, politik sebagai segala kegiatan yang diarahkan untuk mencari dan mempertahankan kekuasaan dalam masyarakat. Keempat, politik sebagai kegiatan yang berkaitan dengan perumusan dan pelaksanaan kebijakan umum. Kelima, politik sebagai konflik dalam rangka mencari dan/atau mempertahankan sumber-sumber yang dianggap penting (Surbakti : 1992 : 2). Kelima cara pandang dalam melihat politik tersebut dapat dijelaskan berikut ini.

\section{Pandangan Klasik}

Sebagimana dikemukakan Aristoteles, pandangan klasik melihat politik sebagai suatu asosiasi warga negara yang berfungsi membicarakan dan menyelenggarakan hal ihwal yang menyangkut kebaikan bersama seluruh anggota masyarakat. Filsuf ini membedakan urusan-urusan yang menyangkut kebaikan bersama (kepentingan publik) dengan urusan-urusan yang menyangkut kepentingan individu atau kelompok masyarakat (swasta). Pada hemat Aristoteles, urusan-urusan yang menyangkut kebaikan bersama memiliki nilai moral yang lebih tinggi dari pada urusan-urusan yang menyangkut kepentingan individu/swasta.

Menurut Aristoteles, manusia merupakan makhluk politik dan sudah menjadi hakikat manusia untuk hidup dalam polis. Hanya dalam polis itu manusia dapat memperoleh sifat moral yang paling tinggi, karena di sana urusan-urusan yang berkenaan dengan seluruh masyarakat akan dibicarakan 
dan diperdebatkan, dan tindakan-tindakan untuk mewujudkan kebaikan bersama akan diambil. Di luar polis manusia dipandang sebagai makhluk yang berderajat di bawah manusia seperti binatang atau sebagai makhluk yang berderajat di atas manusia seperti Dewa atau Tuhan.

Yang menjadi pertanyaan, apakah yang dimaksudkan dengan kepentingan umum atau kebaikan bersama? Apakah yang harus dipandang sebagai isi atau substansi kebaikan bersama? Siapakah yang harus menafsirkan suatu urusan merupakan kepentingan umum atau tidak?.

Rumusan kepentingan umum yang dikemukakan oleh para sarjana sangat bervariasi, sebagian mengatakan kepentingan umum merupakan tujuan-tujuan moral atau nilai-nilai ideal yang bersifat abstrak seperti keadilan, kebajikan, kebahagiaan, dan kebenaran. Sebagian lagi merumuskan kepentingan umum sebagai keinginan orang banyak sehingga mereka membedakan general will (keinginan orang banyak atau kepentingan umum) dari will of all (keinginan banyak orang atau kumpulan keinginan banyak orang).

Sementara itu, ada yang merumuskan kepentingan umum sebagai kepentingan golongan mayoritas. Samuel P. Huntington dalam (Surbakti : 1999 : 3), melukiskan kepentingan umum secara singkat sebagai kepentingan pemerintah karena lembaga pemerintahan dibentuk untuk menyelenggarakan kebaikan bersama.

Konsep politik menurut pandangan klasik ini nampak sangat kabur. Ketidakjelasan ini akan menghadapkan kita kepada kesukaran dalam menentukan patokan kepentingan umum yang disetujui bersama dalam masyarakat. Namun, satu hal yang patut mendapatkan perhatian dari pandangan klasik berupa penekanan yang diberikan pada "apa yang seharusnya" dicapai demi kebaikan bersama seluruh warga negara polis, dan "dengan cara apa sebaiknya" tujuan-tujuan itu dicapai. Dengan kata lain, pandangan klasik lebih menekankan aspek filosofis (idea dan etik) dari pada aspek politik. 
Dalam pengertian politik terkandung tujuan dan etik masyarakat yang jelas. Berpolitik ialah membicarakan dan merumuskan tujuan-tujuan yang hendak dicapai dan ikut serta dalam upaya mengejar tujuan bersama. Barangkali aspek filosifis ini yang merupakan kelebihan, dan arena itu menjadi ciri khas pandangan klasik. Dalam hal ini aspek-aspek filosofis lebih ditekankan dari pada aspek politik. Oleh karena itu metode kajian yang digunakan bukan empirisme, melainkan metode spekulatif-normatif.

\section{Pandangan Kelembagaan}

Pandangan ini melihat politik sebagai hal yang berkaitan dengan penyelenggaraan negara. Dalam hal ini, Max Weber merumuskan negara sebagai komunitas manusia yang secara sukses memonopoli penggunaan paksaan fisik yang sah dalam wilayah tertentu.

Negara dipandang sebagai sumber utama hak untuk menggunakan paksaan fisik yang sah. Oleh karena itu, politik bagi Weber merupakan persaingan untuk membagi kekuasaan atau persaingan untuk mempengaruhi pembagian kekuasaan antar negara maupun antar kelompok di dalam suatu negara. Menurutnya, negara merupakan suatu struktur administrasi atau organisasi yang kongkret, dan ia membatasi pengertian negara semata-mata sebagai paksaan fisik yang digunakan untuk memaksakan ketaatan.

Berdasarkan pendapat Weber tersebut di atas dapat disimpulkan tiga aspek sebagai ciri negara, yaitu :

a. Berbagai struktur yang mempunyai fungsi yang berbeda, seperti jabatan, peranan, dan lembaga-lembaga yang memiliki tugas yang jelas batasnya, yang bersifat kompleks, formal, dan permanen;

b. Kekuasaan untuk menggunakan paksaan dimonopoli oleh negara. Negara yang memiliki kewenangan yang sah untuk membuat keputusan yang final dan mengikat seluruh warga negara. Para pejabatnya mempunyai hak untuk menegakkan keputusan itu seperti menjatuhkan hukuman dan menanggalkan hak milik. Dalam hal ini, 
untuk melaksanakan kewenangan maka negara menggunakan aparatnya seperti polisi, militer, jaksa, hakim, dan petugas lembaga pemasyarakatan.

c. Kewenangan untuk menggunakan paksaan fisik hanya berlaku dalam batas-batas wilayah negara tersebut.

Sebelum perang dunia kedua, para sarjana ilmu politik mengidentifikasikan politik sebagai studi mengenai negara. Dalam hal ini, ada berbagai literatur yang berjudul "pengantar ilmu politik" yang diawali dengan pernyataan ilmu politik bermula dan berakhir dengan negara.

Akan tetapi, saat ini para sarjana ilmu politik tidak lagi menggunakan konseptualisasi itu, sebab mereka berpendapat bahwa politik merupakan gejala serba hadir dalam masyarakat apa saja, yang tidak terbatas pada masyarakat negara atau negara modern. Lalu mereka mencari dan merumuskan konsep politik yang sejauh mungkin dapat diterapkan dalam sebanyak mungkin tempat dan waktu.

Timbul pertanyaan, mengapa mereka tidak lagi menggunakan pandangan kelembagaan? Mereka mengajukan empat kritik terhadap pandangan kelembagaan tersebut. Pertama, konsep itu terlalu sempit, ciri-ciri negara yang disebutkan itu berlaku pada masyarakat yang berbentuk negara, khususnya negara-negara industri maju seperti Eropa Barat, dan Amerika Utara. Sebagaimana diketahui ada berbagai masyarakat suku atau masyarakat yang baru merdeka, yang sekalipun belum memenuhi ciri-ciri negara modern akan tetapi sudah malaksanakan proses dan kegiatan politik.

Masyarakat yang disebutkan terakhir ini belum memenuhi ciri-ciri negara modern, hal tersebut disebabkan antara lain :

a. Belum ada diferensiasi struktur dan spesialisasi peranan yang jelas. Satu struktur melaksanakan lebih dari satu fungsi. Dengan kata lain struktur masyarakatnya masih bersifat sederhana dan informal, akan tetapi kegiatan politik sudah berlangsung. 
b. Tidak memiliki struktur yang memonopoli kewenangan dalam menggunakan paksaan fisik sebab kekuasaan terpencar atau terdistribusi kepada seluruh anggota masyarakat. Sanksi biasanya lebih kepada sanksi moral dan psikologis seperti pengucilan dari pergaulan, sindiran, teguran, dan gossip.

c. Batas wilayah masyarakat belum jelas sebab penduduk cenderung berpindah, termasuk apabila mereka tidak senang kepada pemimpin mereka.

Kedua, di negara-negara industri maju kekuasaan tidak terpusat pada negara melainkan terdistribusikan pada negara-negara bagian, dan kepada berbagai kekuatan politik dalam masyarakat. Ketiga, konseptualisasi di atas terlalu melihat negara dari sudut pandang yuridis-formal sehingga negara cenderung dilihat sebagai gejala yang statis. Keempat, yang melakukan kegiatan bukan lembaga negara (yang tidak memiliki nilai dan kepentingan), tetapi elit yang memegang jabatan tersebut yang ternyata memiliki nilai dan kepentingan sendiri. oleh karena itu, perilaku elit yang memiliki jabatan pada lembaga tersebut yang dipelajari, bukannya lembaganya. Demikian kritik yang diajukan oleh kaum behavioralist.

Akan tetapi, pada tahun 1980-an sejumlah ilmuwan politik Amerika Serikat kembali menjadikan negara sebagai fokus kajian. Mereka memandang negara tidak lagi sekadar arena persaingan kepentingan di antara berbagai kepentingan dalam masyarakat, tetapi juga sebagai lembaga yang memiliki otonomi (terlepas dari pengaruh masyarakat), dan memiliki kemampuan (yang melaksanakan kebijakan yang dibuat sendiri). negara dilihat sebagai lembaga yang memiliki kepentingan yang berbeda dari berbagai kepentingan yang bersaing atau bertentang yang ada di dalam masyarakat. Pandangan ini disebut juga statist perspective (perspektif negara). 


\section{Pandangan Kekuasaan}

Pandangan ketiga, melihat politik sebagai kegiatan mencari dan mempertahankan kekuasaan dalam masyarakat. Oleh karena itu, ilmu politik dirumuskan sebagai ilmu yang mempelajari hakikat, kedudukan, dan penggunaan kekuasaan di manapun kekuasaan itu ditemukan.

Robson dalam (Surbakti : 1999 : 5), merupakan salah seorang yang mengembangkan pandangan tentang kekuasaan mengatakan bahwa, ilmu politik sebagai ilmu yang memusatkan perhatian pada perjuangan untuk memperoleh dan mempertahankan kekuasaan, melaksanakan kekuasaan, mempengaruhi pihak lain, ataupun menentang pelaksanaan kekuasaan. Ilmu politik mempelajari hal ihwal yang berkaitan dengan kekuasaan dalam masyarakat, yakni sifat, hakikat, dasar, proses-proses, ruang lingkup, dan hasil-hasil kekuasaan.

Yang menjadi pertanyaan, apakah yang dimaksud dengan kekuasaan? Menurut pandangan ini, kekuasaan merupakan kemampuan mempengaruhi pihak lain untuk berfikir dan berperilaku sesuai dengan kehendak yang mempengaruhi. Kekuasaan dilihat sebagai interaksi antara pihak yang dipengaruhi dan mempengaruhi, atau yang satu mempengaruhi dan yang lain mematuhi. Hubungan ini selalu diamati dan dipelajari oleh ilmuwan politik yang mengikuti pandangan ketiga ini.

Konsep politik sebagai perjuangan mencari dan mempertahankan kekuasaan juga memiliki sejumlah kelemahan. Pertama, konseptualisasi tersebut tidak membedakan kekuasaan yang beraspek politik dari kekuasaan yang tidak beraspek politik. Misalnya, kemampuan para kiyai atau pendeta untuk mempengaruhi jamaah agar melaksanakan ajaran agama tidaklah beraspek politik. Hal itu karena tidak berkaitan dengan pemerintah selaku pemegang kewenangan yang mendistribusikan nilai-nilai, melainkan menyangkut lingkungan masyarakat yang lebih terbatas. Namun, apabila konseptualisasi di atas diikuti maka kemampuan para pemimpin agama untuk mempengaruhi cara berfikir dan perilaku anggota jamaah termasuk dalam 
kategori kegiatan politik. Kedua, kekuasaan hanya salah satu konsep dalam ilmu politik. Selain kekuasaan, ilmu politik masih memiliki konsep-konsep yang lain seperti kewenangan, legitimasi, konflik, konsensus, kebijakan umum, integrasi politik, dan ideologi. Jadi politik sebagai kegiatan mencari dan mempertahankan kekuasaan semata dalam ilmu politik merupakan konseptualisasi yang sempit dan kurang tajam. Walaupun harus diakui bahwa konsep kekuasaan politik merupakan salah satu konsep yang tidak terpisahkan dari ilmu politik.

\section{Pandangan Fungsionalisme}

Fungsionalisme memandang politik sebagai kegiatan merumuskan dan melaksanakan kebijakan umum. Menyimpang dari pandangan kelembagaan tersebut di atas. Dewasa ini para sarjana politik memandang politik dari kacamata fungsional. Menurut mereka, politik merupakan kegiatan para elit politik dalam membuat dan melaksanakan kebijakan umum.

Di antara sarjana politik yang menggunakan pandangan fungsional dalam mempelajri gejala politik ialah David Easton dan Harold Lasswell. David Easton merumuskan politik sebagai the authoritative allocation of values for a society, atau alokasi nilai-nilai secara otoritatif, berdasarkan kewenangan, dan karena itu mengikat untuk suatu masyarakat.

Oleh karena itu, yang digolongkan sebagai perilaku politik berupa setiap kegiatan yang mempengaruhi (mendukung, mengubah, menentang) proses pembagian dan penjatahan nilai-nilai dalam masyarakat.

Sementara itu, Lasswell menyimpulkan proses politik sebagai masalah who gets what, when, how, atau masalah siapa yang mendapatkan apa, kapan, dan bagaimana. "Mendapatkan apa" artinya mendapatkan nilai-nilai, "Kapan" berarti ukuran pengaruh yang digunakan untuk menentukan siapa yang akan mendapatkan nilai-nilai terbanyak, "Bagaimana" berarti dengan cara apa seseorang mendapatkan nilai-nilai. 
Yang menjadi pertanyaan, apa yang dimaksud dengan nilai-nilai sebagai hal-hal yang diinginkan, hal-hal yang dikejar oleh manusia, dengan derajat kedalaman upaya yang berbeda untuk mencapainya. Nilai-nilai itu ada yang bersifat abstrak berupa prinsip-prinsip hidup yang dianggap baik seperti keadilan, keamanan, kebebasan persamaan, demokrasi, kepercayaan kepada Tuhan yang Maha Esa, kemanusiaan, kehormatan, dan nasionalisme. Di samping yang bersifat abstrak, ada pula nilai-nilai yang bersifat kongkret seperti pangan, sandang, perumahan, fasilitas kesehatan, fasilitas pendidikan, sarana perhubungan, komunikasi, dan rekreasi. Nilai-nilai itu ada yang berupa kebutuhan spiritual, ada pula yang berupa kebutuhan materijasmaniah. Nilai yang abstrak dan kongkrit itu dirumuskan dalam bentuk kebijakan umum yang dibuat dan dilaksanakan oleh pemerintah. Jadi, kegiatan mempengaruhi pemerintah dalam merumuskan dan melaksanakan kebijakan umum berarti mempengaruhi pembagian dan penjatahan nilai-nilai secara otoritatif untuk suatu masyarakat.

Kelemahan pandangan fungsionalisme adalah menempatkan pemerintah sebagai sarana dan wasit terhadap persaingan di antara berbagai kekuatan politik untuk mendapatkan nilai-nilai yang terbanyak dari kebijakan umum. Fungsionalisme mengabaikan kenyataan bahwa pemerintah juga memiliki kepentingan sendiri, baik berupa kepentingan yang melekat pada kepentingan lembaga pemerintah (yang mewakili kepentingan umum), maupun kepentingan para elit yang memegang jabatan (melaksanakan peranan).

Di samping itu, fungsionalisme cenderung melihat nilai-nilai secara instrumental bukan sebagai tujuan seperti yag ditekankan pandangan klasik. Bagi fungsionalisme nilai-nilai sebagai tujuan bersifat sangat relatif karena berbeda dari satu tempat dan waktu ke tempat dan waktu yang lain.

Dalam hal ini, politik tidak dapat pernah bersifat netral, bahwa politik secara ideal seharusnya menyangkut kebaikan bersama. 


\section{Pandangan Konflik}

Menurut pandangan ini, kegiatan untuk mempengaruhi proses perumusan dan pelaksanaan kebijakan umum tiada lain selain upaya untuk mendapatkan dan/atau mempertahankan nilai-nilai. Dalam memperjuangkan hal itu seringkali terjadi perbedaan pendapat, perdebatan, persaingan, bahkan pertentangan yang bersifat fisik di antara berbagai pihak. Dalam hal ini di antara pihak yang berupaya mendapatkan nilai-nilai, dan pihak yang berupaya keras mempertahankan apa yang selama ini telah mereka dapatkan, antara pihak yang sama-sama berupaya keras untuk mendapatkan nilai-nilai yang sama dan pihak yang sama-sama mempertahankan nilai-nilai yang selama ini mereka kuasai.

Perbedaan pendapat, perdebatan, persaingan, bahkan pertentangan dan perebutan dalam mendapatkan dan/atau mempertahankan nilai-nilai disebut konflik. Oleh karena itu menurut pandangan konflik, pada dasarnya politik adalah konflik. Pandangan ini ada benarnya sebab konflik merupakan gejala yang serba hadir dalam masyarakat, termasuk dalam proses politik. Selain itu, konflik merupakan gejala yang melekat dalam setiap proses politik.

Akan tetapi, konseptualisasi ini tidak seluruhnya tepat. Hal tersebut disebabkan selain konflik, konsensus, kerja sama, dan integrasi juga terjadi dalam hampir semua proses politik. Perbedaan pendapat, perdebatan, persaingan, dan pertentangan untuk mendapatkan dan/atau mempertahankan nilai-nilai itu justru diselesaikan melalui proses dialog sehingga sampai pada suatu konsensus maupun diselesaikan lewat kesepakatan dalam bentuk keputusan politik yang merupakan pembagian dan penjatahan nilai-nilai. Oleh karena itu, keputusan politik merupakan upaya menyelesaikan konflik politik.

Kelemahan lain dari konseptualisasi ini ialah konflik tidak semua berdimensi politik sebab selain konflik politik terdapat pula konflik pribadi, konflik ekonomi, konflik agama yang tidak selalu diselesaikan melalui proses politik. Apabila konflik-konflik yang disebutkan terakhir ini berkaitan dengan 
pemerintah atau diselesaikan melalui proses politik maka konflik-konflik yang semula tidak berdimensi politik berkembang menjadi konflik politik.

Dari segi metodologi, kelima pandangan ini acapkali dikelompokkan menjadi dua kategori umum, yakni tradisionalme dan behavioralisme. Ilmu politik tradisionalisme memandang gejala politik dari segi normatif, dan menganggap tugas ilmu politik untuk memahami dan memberikan gejala politik, bukan menjelaskan apalagi memperkirakan apa yang akan terjadi. Ilmu politik tradisional melihat politik sebagai perwujudan tujuan masyarakat-negara. Termasuk ilmu politik tradisional dalam hal ini berupa pandangan klasik dan pandangan kelembagaan.

Behavioralisme memandang politik dari segi apa adanya (what it is) yang berupaya menjelaskan mengapa gejala politik tertentu terjadi, kalau mungkin juga memperkirakan gejala politik apa yang akan terjadi. Behavioralisme memandang politik sebagai kegiatan (perilaku), yang berawal dari asumsi terdapat keajegan atau pola dalam perilaku manusia. Oleh karena itu, politik sebagai pola perilaku dapat dijelaskan dan diperkirakan. Termasuk behavioralisme dalam hal ini berupa pandangan kekuasaan, pandangan konflik, dan pandangan fungsionalisme. 


\section{BAB II \\ SISTEM POLITIK}

Sistem politik adalah keseluruhan unit-unit politik yang saling berkaitan satu dengan yang lain untuk mempengaruhi proses politik. Bagianbagian atau unit-unit dari sistem politik terdiri dari input, proses, dan output. Berbagai macam input-input ini lalu kemudian diubah oleh proses-proses yang terjadi di dalam sistem tersebut menjadi output, yang selanjutnya output-output tersebut menimbulkan kembali pengaruh terhadap sistem itu sendiri maupun terhadap lingkungan di mana sistem itu berada. Rumusan ini sangat sederhana akan tetapi cukup memadai untuk menjelaskan berbagai hal seperti input - proses - output. Hubungan ini secara diagram dapat dilihat dalam gambar berikut ini. Diagram di bawah ini merupakan suatu model yang sangat sederhana yang dapat digunakan sebagai pendekatan dalam mempelajari kehidupan politik.

\section{LINGKUNGAN}

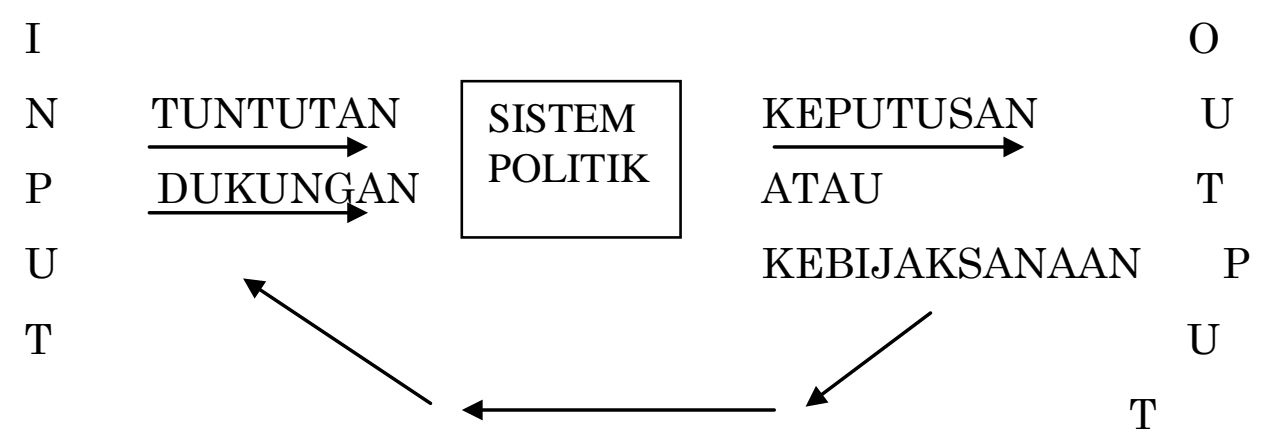

LINGKUNGAN

Sebagai suatu sistem, tentu saja sistem politik memiliki ciri-ciri tertentu. Untuk memberikan gambaran yang menyeluruh tentang pendekatan ini, berikut ini adalah ciri-ciri utama dari sistem politik. 


\section{Ciri-ciri Identifikasi.}

Untuk membedakan sistem politik dengan sistem sosial lainnya, kita harus bisa mengidentifikasikannya dengan menggabarkan unit-unit dasarnya dan membuat garis batas yang memisahkan unit-unit itu dari unit-unit yang ada di luar sistem politik itu.

(a) Unit-unit Sistem Politik.

Unit-unit adalah adalah unsur-unsur yang membentuk suatu sistem.

Dalam sistem politik, unit-unit ini bewrwujud tindakan-tindakan politik. Perlu sekali memperhatikan tindakan-tindakan ini karena merekalah yang membentuk peranan-peranan politik dan kelompokkelompok politik.

(b) Perbatasan.

Sistem politik selalu berada dalam atau dikelilingi oleh lingkungan berupa sistem-sistem lain. Tidak ada sistem yang hidup dalam lingkungan yang kosong. Cara berfungsinya suatu sistem sebagian merupakan perwujudan dari upayanya untuk menanggapi keseluruhan lingkungan sosial, biologis, dan fisiknya.

Suatu sistem politik memiliki perbatasan dalam pengertian yang sama dengan yang dimiliki oleh suatu sistem fisik. Yang termasuk dalam suatu sistem politik adalah semua tindakan yang lebih kurang langsung berkaitan dengan pembuatan keputusan yang mengikat masyarakat; dan setiap tindakan sosial yang tidak mengandung ciri tersebut tidak termasuk di dalam sistem politik, sehingga secara otomatis akan dipandang sebagai variabel eksternal di dalam lingkungan sistem tersebut. 


\section{Input dan Output}

Input merupakan tuntutan dan dukungan, sedangkan output merupakan keputusan yang otoritatif atau kebijakan umum yang mengikat seluruh masyarakat.

Untuk menjamin tetap bekerjanya suatu sistem diperlukan input-input secara ajeg. Tanpa input sistem tidak akan dapat berfungsi - begitu pula tanpa adanya output kita tidak dapat mengidentifikasikan pekerjaan yang dikerjakan oleh sistem tersebut.

David Easton dalam (Afan Gaffar : 1983 : 11), melakukan telaah tegas atas kehidupan politik dalam kaitannya dengan sistem, dan memperkenalkan dua macam input ke dalam sistem politik, yaitu tuntutan dan dukungan. Klasifikasi di bawah ini akan memberikan gambaran nyata tentang jarak dan variasi dari input tuntutan, yaitu :

a. Tuntutan untuk memperoleh barang-barang dan pekerjaan seperti upah, jam kerja, pendidikan, fasilitas rekreasi, dan transportasi.

b. Tuntutan pengaturan tingkah laku seperti jaminan keselamatan, Kontrol atas harga, dan tuntutan akan adanya suatu peraturan yang menyangkut suatu permasalahan sosial.

c. Tuntutan untuk berpartisipasi dalam sistem politik seperti, hak pilih, kesempatan untuk menjadi pegawai negeri, dan kesempatan untuk mengorganisir kekuatan politik formal, dan lain-lain.

d. Tuntutan untuk mendapatkan informasi, dan komunikasi seperti, permintaan keterangan dari pemerintah atas suatu kebijakan umum yang sementara dibuat atau dilaksanakan, dan tuntutan untuk menyatakan aspirasi.

Suatu tuntutan dapat dinyatakan dalam berbagai bentuk, derajat, serta intensitas yang berbeda-beda.

Sedangkan input dukungan dapat diperinci ke dalam empat bagian besar, yaitu : 
a. Dukungan materi, seperti ketaatan membayar pajak, kesediaan bekerja dalam pelayanan umum.

b. Kepatuhan pada hukum, dan peraturan perundang-undangan, dan undang-undang.

c. Dukungan partisipatif, seperti ikut serta menggunakan hak pilih dalam suatu pemilihan umum, diskusi politik, dan semua kegiatan politik lainnya.

d. Memperhatikan segala sesuatu yang diumumkan oleh pemerintah, hak pemerintah, simbol-simbol kenegaraan, dan perayaan-perayaan nasional.

Jika suatu sistem politik tanggap atas semua tuntutan yang berkembang ditengah-tengah masyarakat dan berupaya untuk memprosesnya secara efektif, maka dukungan dan peran serta dari masyarakat akan diperoleh. Secara umum dapat dikatakan bahwa tuntutan akan menghasilkan keputusan / kebijaksanaan umum, sedangkan dukungan dari masyarakat akan mempermudah suatu sistem politik untuk membuat output atau kebijakan umum.

\section{Diferensiasi Dalam Suatu Sistem}

Input merupakan energi bagi suatu sistem politik dan juga sekaligus merupakan sumber informasi yang berharga bagi para pengambil keputusan politik. Input-input ini lalu kemudian diproses menghasilkan jenis output yang berbeda dengan input yang diperolehnya dari lingkungannya. Pekerjaan mengubah input menjadi output yang berbeda-beda dalam waktu yang terbatas membuat struktur suatu sistem politik harus mengenal diferensiasi minimal seperti pembagian kerja bagi anggota-anggotanya, dan menyediakan suatu struktur yang bervariasi sehingga dapat menampung pekerjaan yang berbeda-beda dan harus diselesaikan pada saat yang sama. 


\section{Integrasi Dalam Suatu Sistem}

Bila suatu sistem ingin mempertahankan dirinya dari kehancuran, sistem tersebut harus memiliki suatu mekanisme yang bisa mengitegrasikan (menyatukan) atau bahkan memaksa para anggotanya untuk bekerjasama walaupun dalam kadar minimal sehingga mereka dapat membuat keputusankeputusan yang otoritatif.

\section{A. Pengertian : Input tuntutan dan Input Dukungan}

\section{Input : Tuntutan}

Input tuntutan ini pada dasarnya merupakan bahan baku, dan sekaligus merupakan informasi yang berharga bagi sebuah sistem politik yang berasal dari masyarakat untuk mengambil suatu keputusan/kebijakan umum. Tuntutan berasal dari orang-orang atau kelompok-kelompok yang ada di tengah masyarakat yang merasa tidak puas dengan keadaan yang ada. Ketidakpuasan tersebut dapat berupa kelangkaan akan sebagian besar hal-hal atau benda-benda yang bernilai tinggi.

Beberapa dari tuntutan akan nilai-nilai yang relatif langka itu tidak pernah masuk ke dalam sistem politik sebelum dipenuhi melalui perundinganperundingan pribadi. Input tuntutan itu dapat berupa : pendidikan, lapangan kerja, gaji, fasilitas kerja, harga-harga, suplai kebutuhan pokok, lingkungan hidup, masalah kegamaan, gender, moral, kebudayaan dan lain-lain.

Input tuntutan dapat dibagi ke dalam dua macam, yaitu tuntutan eksternal dan tuntutan internal :

1. Tuntutan eksternal.

Tuntutan eksternal adalah tuntutan yang berasal dari luar sebuah sistem politik. Lingkungan sistem politik ini terdiri dari sistem-sistem lain seperti ekonomi, kebudayaan, ekologi, pribadi-pribadi, dan demografi. Masingmasing sistem tersebut merupakan suatu kumpulan besar variabel-variabel 
yang membantu atau mempengaruhi pembentukan jenis tuntutan yang masuk ke dalam sistem politik.

2. Tuntutan internal.

Jenis tuntutan ini berbeda dengan pengertian tuntutan eksternal, yaitu sebuah tuntutan yang berasal dari luar sistem politik.. Sangat perlu bagi kita untuk membedakan tuntutan internal dengan tuntutan eksternal oleh karena tuntutan internal bukanlah input yang dimasukkan ke dalam sistem politik, akan tetapi merupakan suatu jenis tuntutan yang timbul dari dalam sistem itu sendiri atau disebut juga dengan withinput.

Bagaimana agar tuntutan-tuntutan tersebut dapat diubah menjadi isuisu politik dan faktor apa yang menentukan sehingga suatu tuntutan dapat menjadi suatu masalah yang dapat menimbulkan diskusi politik yang serius, atau tetap merupakan sesuatu yang harus diselesaikan secara pribadi oleh anggota masyarakat tersebut?

Timbulnya suatu tuntutan, baik internal maupun eksternal tidak begitu saja akan menjadi sebuah isu politik yang mendapat perhatian para pengambil keputusan. Banyak tuntutan yang hilang begitu saja begitu diajukan kepada pembuat keputusan / pembuat kebijakan umum, ataukah proses pengajuannya seret dan bertele-tele hanya karena didukung oleh anggota masyarakat yang kurang berpengaruh dan tidak pernah bisa masuk ke dalam tingkat pembuatan keputusan, sedangkan yang lain mungkin menjadi isu politik. Isu politik merupakan suatu tuntutan yang oleh anggota-anggota masyarakat ditanggapi dan dianggap sebagai hal yang penting untuk dibahas melalui saluran-saluran yang diakui dalam sistem itu.

Bila kita ingin memahami proses perubahan tuntutan menjadi isu, maka kita harus mendapatkan data yang cukup seperti ; (a) mengetahui hubungan antara suatu tuntutan dengan lokasi dari pencetusnya atau pendukungnya dalam struktur kekuasaan pada masyarakat tersebut, (b) pentingnya kerahasiaan jika dibandingkan dengan publisitas atau keterbukaan dalam mengajukan tuntutan tersebut, (c) masalah waktu 
diajukannya tuntutan tersebut, (d) kecakapan dan pengetahuan politik, (e) penguassan saluran komunikasi, (f) sikap dan suasana pemikiran masyarakat, dan (g) gambaran yang dimiliki oleh pencetus tuntutan itu mengenai cara kerja sistem politik tertentu. Jawaban terhadap masalah-masalah ini mungkin akan merupakan suatu indeks pengubahan atau konversi yang mencerminkan probabilitas bagi suatu kumpulan tuntutan untuk bisa diubah menjadi sebuah isu politik yang hidup.

\section{B. Input : Dukungan}

Untuk dapat tetap mempertahankan kelangsungan hidupnya, suatu sistem politik juga memerlukan energi dalam bentuk dukungan. Bentukbentuk dukungan itu berupa tindakan-tindakan atau pandangan-pandangan yang memajukan ataukah merintangi sistem politik. Jadi input dukungan berfungsi untuk merintangi ataukah memajukan suatu pengambilan keputusan atau kebijakan umum. Jenis input ini disebut juga dengan support inputs.

Tanpa dukungan, tuntutan tidak akan bisa terpenuhi atau konflik mengenai tujuan tidak akan terselesaikan. Jika sebuah tuntutan ingin mendapatkan tanggapan, kelompok kepentingan yang memperjuangkan satu tuntutan menjadi sebuah keputusan/kebijakan umum yang mengikat, maka kelompok kepentingan tersebut harus mampu memperoleh dukungan dari pihak-pihak lain yang ada di dalam sistem politik tersebut.

Menurut David Easton dalam (Mas'oed dan MacAndrews : 2000 : 12), tingkah laku mendukung ada dua macam; (a) Tindakan-tindakan yang mendorong pencapaian tujuan, kepentingan, dan tindakan orang lain yang mungkin berwujud memberikan suara yang mendukung, membela, atau mempertahankan tindakan tersebut. tindakan mendukung dalam bentuk tindakan nyata dan terbuka ini disebut juga dengan istilah over action.

Sebaliknya, tingkah laku mendukung ini mungkin tidak berwujud tindakan yang nampak nyata dari luar, tetapi merupakan bentuk-bentuk 
tingkah laku "batiniah" yang kita sebut pandangan atau suasana pemikiran. Suasana pemikiran yang mendukung (supportif) merupakan kumpulan sikapsikap atau kecendrungan-kecendrungan yang kuat, ataukah suatu kesediaan untuk bertindak demi orang lain. Dalam tahap ini, memang tidak ada tindakan nyata atau terbuka akan tetapi implikasinya jelas bahwa seseorang mungkin akan melakukan suatu tindakan yang searah dengan sikapnya. Bila seseorang yang kita anggap memiliki suasana pemikiran tertentu ternyata tidak bertingkah laku atau tidak bertindak sesuai dengan suasana pemikiran tersebut, maka kita berasumsi bahwa kita tidak cukup dalam memahami dan menyelami perasaan yang sebenarnya dari orang tersebut dan hanya memperhatikan sikap yang tampak dari luar saja.

\section{Mekanisme Dukungan}

Tidak ada satu sistem politik yang dapat menghasilkan output berupa keputusan-keputusan yang otoritatif jika dukungan, di samping tuntutan tidak memperoleh jalan masuk ke dalam sistem politik. Dukungan merupakan input yang penting bagi suatu sistem politik. Dukungan bagi suatu sistem haruslah dipelihara dan dikelola menjadi suatu arus dukungan yang tetap oleh karena tanpa arus dukungan yang tetap dan ajeg suatu sistem tidak akan bisa menyerap energi yang cukup memadai untuk mengubah tuntutan menjadi keputusan. Terdapat berbagai sarana yang bisa digunakan oleh unitunit politik untuk dapat menyalurkan dukungan pada suatu sistem politik.

\section{Output-output Sebagai Mekanisme Dukungan}

Output dari suatu sistem politik dapat berwujud pada suatu keputusan atau kebijakan umum. Salah satu cara untuk memperkuat ikatan antara warga negara dengan sistem politiknya adalah dengan cara menciptakan atau membuat keputusan-keputusan yang dapat memenuhi tuntutan-tuntutan warga dari sebuah sistem politik. Output yang berwujud keputusan atau 
kebijakan umum merupakan pendorong khas bagi anggota-anggota dari suatu sistem politik untuk memberikan dukungannya.

Sifat dukungan ada dua, bisa positif juga sebaliknya bisa negatif. Bila dukungan itu negatif, ada kemungkinan dukungan itu diberikan oleh karena pemberi dukungan takut terhadap hukuman. Sehingga dukungan yang diberikan sebagiannya hanyalah merupakan akibat dari ketakutan akan sanksi-sanksi atau karena paksaan.

\section{Politisasi Sebagai Mekanisme Dukungan}

Begitu seorang individu lahir dan tumbuh dalam suatu masyarakat, maka pada dasarnya ia hidup dengan anggota masyarakat lainnya dalam suatu jaringan ganjaran dan hukuman (network of rewards and Funishment), berkomunikasi dengannya, dan menanamkan berbagai jenis tujuan dan norma yang telah melembaga dalam masyarakat, ilmu sosiologi menamakannya dengan istilah proses sosialisasi. Melalui proses sosialisasi ini seorang individu belajar untuk memainkan berbagai peranan sosialnya. Sebagian dari tujuantujuan dan norma-norma ini berkaitan dengan hal-hal yang bersifat politik yang dianggap bermanfaat dari masyarakat tersebut. Mengenai cara dan bagaimana anggota masyarakat mempelajari pola-pola politik ini, disebut dengan istilah politisasi politik.

Proses politisasi masyarakat, pada awalnya dimulai ketika seorang anak meningkat dewasa harus menyerap berbagai orientasi dan sikap terhadap masalah-masalah politik yang diharapkan dimiliki oleh setiap orang dalam masyarakat tersebut. Bila harapan-harapan anggota masyarakat mengenai cara bagaimana seharusnya setiap orang bertingkah laku dalam situasi-situasi politik tertentu berbeda jauh, maka tidak mungkin dilakukan tindakan bersama dalam membuat keputusan-keputusan yang mengikat.

Agar suatu sistem politik dapat tetap berfungsi dengan tertib dan tidak hancur, anggota-anggota sistem tersebut harus memeliki harapan dasar yang sama dalam hal patokan-patokan atau ukuran-ukuran yang harus diterapkan 
untuk membuat penilaian politik, cara seorang berpikir tentang berbagai masalah politik, dan cara anggota-anggota sistem memandang dan menafsirkan gejala politik.

Mekanisme yang dipakai selama proses balajar ini, dan yang sangat relevan dengan proses politisasi adalah yang pertama, proses belajar atau politisasi bagi individu tidak pernah berhenti yang dimulai dari masa kanakkanak. Kedua, politisasi melibatkan suatu jaringan ganjaran dan hukuman. Dengan menyelaraskan diri dengan masyarakat kita akan mendapatkan keuntungan karena dihormati, kekayaan, kesempatan-kesempatan yang lebih baik. Akan tetapi kalau kita mengingkari masyarakat di luar batas, kita akan ditolak, tidak dihargai, dan seringkali menderita kerugian material. Ketiga, komunikasi yang berulang-ulang mengenai tujuan-tujuan dan norma-norma kepada seluruh anggota masyarakat melalui mitos, doktrin, dan filsafat politik dalam rangka menanamkan suatu penafsiran tertentu mengenai tujuantujuan dan norma-norma kepada setiap generasi. Unsur-unsur yang sangat menentukan dalam proses penanaman dan pewarisan nilai-nilai tersebut adalah orang tua, saudara, teman sepergaulan, guru, organisasi dan pemimpin masyarakat, serta lambang-lambang negara seperti bendera, upacara-upacara yang dipenuhi makna politik.

Bila keterikatan (attachment) politik itu menjadi mengakar dan sangat kuat melembaga ditengah masyarakat, sistem politik tersebut telah memiliki legitimasi yang tinggi. Dengan demikian, politisasi secara efektif bisa membentuk jalan dengan mana ukuran-ukuran legitimasi diciptakan dan diwariskan kepada generasi berikutnya dalam sistem politik tersebut. secara empiris terbukti bahwa suatu sistem politik dapat bertahan hidup lama disebabkan oleh dukungan yang ditumbuhkan dan dipelihara oleh keyakinan yang mendalam akan legitimasi pemerintahannya. Keyakinan yang mendalam tersebut diperoleh melalui proses politisasi. 


\section{BAB III \\ SOSIALISASI POLITIK, BUDAYA POLITIK, DAN PARTISIPASI \\ POLITIK}

\section{A. SOSIALISASI POLITIK}

\section{Pengertian Sosialisasi Politik.}

Berbagai pengertian dan batasan mengenai sosialisasi politik sebagaimana dikemukakan oleh para sarjana terkemuka yang dirangkum oleh Sri Jutmini dan Winarno (2007 : 17), adalah sebagai berikut :

\section{a. Kenneth P. Langton}

Sosialisasi politik dalam pengertian luas merujuk pada cara masyarakat dalam mentransmisikan budaya politiknya dari generasi ke generasi

\section{b. Richard E. Dawson}

Sosialisasi politik dapat dipandang sebagai pewarisan pengetahuan, nilai-nilai dan pandangan-pandangan politik dari orang tua, guru, dan saranasarana sosialisasi lainnya kepada warga negara baru dan mereka yang menginjak dewasa.

\section{c. Dennis Kavanagh}

Sosialisasi politik adalah istilah yang digunakan untuk menggambarkan proses di mana individu belajar tentang politik dan mengembangkan orientasi terhadap politik.

\section{d. Prewitt dan Dawson}

Sosialisasi politik didefinisikan sebagai proses bagaimana warga negara memperoleh pandangan-pandangan politik yang merupakan perkumpulan cara yang telah menjadi pegangan bagi kehidupan politik bangsanya. 


\section{e. Cholisin}

Sosialisasi politik merupakan proses transmisi orientasi politik dan budaya politik bangsanya (sistem politik nasionalnya) agar warga negara memiliki kematangan politik (sadar akan hak dan kewajibannya sesuai dengan yang ditentukan dalam politik nasionalnya).

Sosialisasi politik sebagaimana yang dikemukakan oleh Gabriel Almond dan Sidney Verba dalam (Mas'oed dan MacAndrews : 2000 : 34), adalah bagian dari proses sosialisasi yang khusus membentuk nilai-nilai politik yang menunjukkan bagaimana seharusnya masing-masing anggota masyarakat berpartisipasi dalam sistem politiknya. Kebanyakan anak-anak, sejak masa kanak-kanaknya belajar memahami sikap-sikap dan harapan-harapan politik yang hidup dalam masyarakatnya.

Jadi sosialisasi politik menunjuk pada proses-proses pembentukan sikap-sikap politik dan pola-pola tingkah laku. Di samping itu sosialisasi poltik juga merupakan sarana bagi suatu generasi untuk "mewariskan" patokanpatokan dan keyakian-keyakinan politik kepada generasi sesudahnya. Proses ini disebut transmisi kebudayaan.

Teradapat dua hal yang harus diperhatikan mengenai proses sosialisasi politik ini. Pertama, sosialisai ini berjalan terus menerus selama hidup seseorang. Sikap-sikap yang terbentuk selama masa kanak-kanak selalu disesuaikan atau diperkuat sementara ia menjalani berbagai pengalaman sosial. Pengaruh keluarga pada masa anak-anak mungkin menciptakan gambaran-gambaran yang baik mengenai suatu partai politik tertentu dalam pemikiran seseorang, tetapi pendidikan sekolah, pengalaman bekerja, dan pengaruh pergaulan mungkin saja merubah gambaran itu dengan dramatis. Juga peristiwa-peristiwa dan pengalaman-pengalaman tertentu seperti perang besar atau malaise ekonomi akan meninggalkan bekas yang dalam pada seluruh masyarakat. Bagi anggota-anggota masyarakat yang lebih tua, pengalaman-pengalaman ini dapat menimbulkan resosialisasi, yaitu 
perubahan drastis dalam sikap-sikap mereka terhadap lembaga-lembaga politik yang ada. Tetapi pengaruh dari peristiwa-peristiwa semacam ini rupanya paling banyak menimpa golongan pemilih (electrorate) yang berusia muda, yang mempunyai sikap-sikap yang lebih fleksibel terhadap sistem politiknya.

Kedua, sosialisasi politik dapat berwujud transmisi dan pengajaran yang langsung maupun tidak langsung. Sosialisasi bersifat langsung kalau melibatkan komunikasi informasi, nilai-nilai atau perasaan-perasaan mengenai politik secara eksplisit. Mata pelajaran kewarganegaraan di sekolah-sekolah merupakan contoh dari sosialisasi politik langsung. Sosialisasi politik tak langsung terutama sangat kuat berlangsung di masa kanak-kanak - sejalan dengan berkembangnya sikap penurut atau sikap pembangkang terhadap orang tua, guru, dan teman, yaitu sikap-sikap yang cenderung mempengaruhi sikapnya di masa dewasa terhadap pemimpin-pemimpin politiknya dan terhadap sesama warga negara.

Sosialisasi politik membentuk dan "mewariskan" kebudayaan politik suatu bangsa. Sosialisasi politik juga bisa memelihara kebudayaan politik suatu bangsa dalam bentuk pewarisan kebudayaan itu oleh suatu generasi kepada generasi berikutnya. Sosialisasi politik juga bisa merubah kebudayaan politik, yaitu bila sosialisasi itu bisa menyebabkan penduduk atau sebagian penduduk, melihat atau mengalami kehidupan politik dijalankan dengan cara lain. Pada waktu terjadi perubahan besar atau peristiwa-peristiwa luar biasa, misalnya terbentuknya negara baru, sosialisasi politik bahkan dapat menciptakan kebudayaan politik yang baru. Memelihara, merubah, dan menciptakan kebudayaan politik adalah macam-macam fungsi yang dijalankan oleh sosialisasi politik.

Kebudayaan politik seringkali berubah secara dramatis karena adanya perang atau revolusi. Kadang-kadang perubahan ini disengaja, yaitu merupakan tujuan daripada pemimpin-pemimpin atau golongan-golongan politik. Tetapi perubahan kebudayaan politik itu mungkin juga terjadi akibat 
tanggapan yang tidak direncanakan dan tidak disengaja dari kelompokkelompok atau segenap masyarakat terhadap pengaruh dari peristiwaperistiwa besar. Jerman Barat (Jerman saat ini) dan Kuba merupakan contoh masyarakat yang mengalami perubahan kebudayaan di bidang politiknya.

\section{Tipe Sosialisasi Politik}

Tipe sosialisasi politik yang dimaksud adalah bagaimana cara atau mekanisme sosialisasi politik berlangsung. Oleh karena itu, tipe sosialisasi politik dapat disebut pula dengan mekanisme sosialisasi politik. Ada dua tipe sosialisasi politik yaitu tidak langsung dan langsung.

a. Sosialisasi politik tidak langsung

Sosialisasi politik tidak langsung adalah warga negara pada mulanya berorientasi pada hal-hal yang bukan politik (non-politik), namun kemudian mempengaruhinya untuk memiliki orientasi politik. Terdapat dua tahap dalam sosialisasi politik tidak langsung yaitu tahap pertama berorientasi pada non-politik, tahap kedua - orientasi pertama digunakan untuk orientasi pada politik. Sosialisasi politik secara tidak langsung ini dapat dilakukan melalui dua cara :

$>$ Pengalihan Hubungan Antar Individu

Hubungan antar individu yang pada mulanya tidak berkaitan dengan politik, namun nantinya akan terpengaruh ketika berhubungan atau berorientasi dengan kehidupan politik. Contohnya, hubungan mahasiswa dengan dosen nantinya akan membentuk siswa manakala ia bertemu dengan bupati.

$>$ Magang

Magang merupakan bentuk aktivitas sebagai sarana belajar. Magang di tempat-tempat tertentu atau organisasi non-politik, nantinya akan mempengaruhi seseorang ketika berhubungan dengan politik. Contohnya, mahasiswa ikut organisasi kemahasiswaan, dalam organisasi tersebut mereka belajar mengenai rapat, melakukan voting, 
dan membuat keputusan. Kegiatan ini akan sangat membantu manakala mahasiswa nanti benar-benar terjun ke dalam dunia politik praktis.

$>$ Generalisasi

Kepercayaan dan nilai-nilai yang diyakini selama ini yang sebenarnya tidak ada kaitannya secara langsung dengan politik dapat mempengaruhi seseorang untuk berorientasi pada objek politik tertentu. Contohnya, seseorang yang memiliki kepercayaan bahwa semua orang pada dasarnya baik, maka kepercayaan ini akan menjadikan ia berprasangka baik terhadap semua pejabat negara. Sebaliknya, jika seseorang berpendapat bahwa semua orang pada dasarnya buruk, ia akan hati-hati manakala bertemu dengan pejabat. Jadi kepercayaan atau nilai-nilai yang diyakini digeneralisasikan kepada kehidupan politik.

\section{b. Sosialisasi Politik Langsung}

Tipe sosialisasi politik langsung berlangsung dalam satu tahap saja, yaitu bahwa hal-hal yang diorientasikan dan ditransmisikan adalah hal-hal yang bersifat politik saja. Sosialisi politik langsung dapat dilakukan melalui beberapa cara yaitu sebagai berikut :

$>$ Peniruan Perilaku (imitasi)

Proses menyerap atau mendapatkan orientasi politik dengan cara meniru orang lain. Yang ditiru bukan hanya pandangan politik, tetapi juga sikap-sikap politik, keyakinan politik, harapan mengenai politik, tingkah laku politik, serta keterampilan dalam berpolitik.

$>$ Sosialisasi Antisipatori

Sosialisasi politik dengan cara belajar bersikap dan berperilaku seperti tokoh politik yang diidealkan.

> Pendidikan Politik 
Sosialisasi politik melalui pendidikan politik adalah upaya yang secara sadar dan sengaja serta direncanakan untuk menyampaikan, menanamkan, dan memberikan pelajaran kepada anak untuk memiliki orientasi politik tertentu. Pendidikan politik bisa dilakukan di sekolah, organisasi, partai politik, media massa, diskusi politik, serta forumforum politik.

$>$ Pengalaman Politik

Pengalaman politik adalah belajar langsung dalam kegiatan-kegiatan politik atau kegiatan-kegiatan yang sifatnya publik. Terlibat langsung dalam kegiatan partai politik.

\section{Sarana Sosialisasi Politik}

Sosialisasi dijalankan melalui bermacam-macam lembaga. Beberapa diantaranya seperti pelajaran kewarganegaraan di sekolah-sekolah dengan sengaja direncanakan demi tujuan sosialisasi politik. Berikut ini adalah beberapa sarana sosialisasi politik.

Keluarga, pengaruh kehidupan keluarga baik yang langsung maupun yang tidak langsung - yang merupakan struktur sosialisasi pertama yang dialami seseorang - sangat kuat dan kekal. Yang paling jelas pengaruhnya dari keluarga adalah dalam hal pembentukan sikap terhadap wewenang kekuasaan (authority). Keluarga biasanya membuat keputusan bersama, dan bagi si anak keputusan-keputusan yang dibuat itu bisa otoritatif, dalam arti keengganan untuk mematuhinya dapat mengundang hukuman. Pengalaman berpartisipasi dalam pembuatan keputusan keluarga dapat meningkatkan perasaan kompetensi politik si anak, memberinya kecakapan-kecakapan untuk melakukan interaksi politik, serta membuatnya lebih mungkin berpartisipasi dengan aktif dalam sistem politik sesudah menjadi dewasa. Keluarga juga membentuk sikap-sikap politik masa depan dengan menempatkan individu dalam dunia kemasyarakatan luas; dengan membentuk ikatan-ikatan etnik, linguistik, religius, dan kelas sosialnya; dengan memperkuat nilai-nilai dan 
prestasi kultural dan pendidikannya; dan dengan mengarahkan aspirasiaspirasi pekerjaan dan ekonominya.

Sekolah, orang yang terpelajar lebih sadar akan pengaruh pemerintah terhadap kehidupan mereka, lebih memperhatikan kehidupan politik, memperoleh lebih banyak informasi tentang proses-proses politik, dan lebih kompeten dalam tingkah laku politiknya.

Sekolah memberi pengetahuan kepada kaum muda tentang dunia politik dan peranan mereka di dalamnya. Sekolah memberi pandangan yang lebih konkrit tentang lembaga-lembaga politik dan hubungan-hubungan politik. Sekolah juga merupakan saluran pewarisan nilai-nilai dan sikap-sikap masyarakatnya. Sekolah dapat memegang peranan penting dalam pembentukan sikap-sikap terhadap "aturan permainan politik" (rule of the political game) yang tidak tertulis seperti menanamkan nilai-nilai kewajiban warganegara, hubungan politik informal, dan integritas politik. Sekolah dapat mempertebal kesetiaan terhadap sistem politik dan memberikan simbol-simbol umum untuk menunjukkan tanggapan yang ekspresif terhadap sistem itu, seperti bendera nasional, dan ikrar kesetiaan "padamu negeri". Pengajaran sejarah nasional juga berfungsi memperkuat kesetiaan kepada sistem politik.

Kelompok Pergaulan, Meskipun sekolah dan keluarga merupakan sarana yang paling jelas terlibat dalam proses sosialisasi, ada juga beberapa unit social lain yang bisa membentuk sikap-sikap politik seseorang. Salah satunya adalah kelompok pergaulan, termasuk kelompok bermain di masa kanak-kanak, kelompok persabatan, dan kelompok kerja yang kecil, di mana setiap anggota mempunyai kedudukan yang relatif sama dan saling memiliki ikatan-ikatan yang erat. Setiap individu dalam kelompok itu menyesuaikan pendapatnya dengan teman-temannya mungkin karena ia menyukai atau menghormati mereka, atau mungkin pula karena ia ingin sama dengan mereka. Jadi kelompok pergaulan itu mensosialisasikan angota-anggotanya dengan cara mendorong atau mendesak mereka untuk menyesuaikan diri terhadap sikap-sikap atau tingkah laku yang dianut olah kelompok itu. 
Seseorang mungkin menjadi tertarik pada politik, atau mulai mengikuti peristiwa-peristiwa politik karena teman-temannya berbuat begitu. Seorang anak lulusan sekolah menengah mungkin memilih masuk ke suatu perguruan tinggi karena pelajar-pelajar lain temannya berbuat hal serupa. Dalam hal ini, individu tersebut merubah kepentingan dan tingkah lakunya agar sesuai dengan kelompoknya sebagai usaha agar ia tetap diterima oleh anggotaanggota kelompok tersebut.

Pekerjaan, Pekerjaan - dan organisasi-organisasi formal maupun nonformal yang dibentuk berdasar lingkungan pekerjaan tersebut, seperti serikat buruh, klub sosial, dan semacamnya - juga merupakan saluran komunikasi informasi dan keyakinan yang jelas. Individu-individu mengidentifikasikan diri dengan suatu kelompok tertentu dan menggunakan kelompok itu sebagai acuan (reference) dalam kehidupan politik. Mereka menjadi sensitif terhadap norma-norma kelompok itu dan menilai tidakantindakannya berdasar perhitungan apa yang paling baik bagi kelompok itu.

Berpartisipasi dalam suatu tawar-menawar kolektif atau dalam suatu demonstrasi dapat merupakan pengalaman sosialisasi yang berkesan mendalam baik bagi pihak buruh maupun pihak majikan. Buruh yang berdemonstrasi dapat mengetahui bahwa ia dapat mempengaruhi bentuk keputusan yang akan mempengaruhi masa depannya yang sedang dibuat, di samping ia juga dapat memperoleh pengetahuan tentang kecakapankecakapan bertindak tertentu seperti berdemonstrasi dan mogok, yang bisa berguna kelak ketika ia berpartisipasi lagi dalam bentuk-bentuk kegiatan politik lain.

Media Massa. Masyarakat modern tidak dapat hidup tanpa komunikasi yang luas, cepat, dan secara umum seragam. Informasi tentang peristiwaperistiwa yang terjadi di mana saja di dunia segera menjadi pengetahuan umum dalam beberapa jam saja. Sebagian besar masyarakat dunia - terutama bagian-bagiannya yang modern - telah menjadi satu kelompok penonton tunggal, yang tergerak hatinya oleh peristiwa-peristiwa yang sama dan 
dirangsang oleh selera yang sama. Kita tahu bahwa media massa - surat kabar, radio, televisi, majalah - memegang peranan penting dalam menularkan sikap-sikap dan nilai-nilai modern kepada bangsa-bangsa yang baru merdeka.

Di samping memberikan informasi tentang peristiwa-pristiwa politik, media massa juga menyampaikan, langsung maupun tidak, nilai-nilai utama yang dianut oleh masyarakatnya. Beberapa simbol tertentu disampaikan dalam suatu konteks emosional, dan peristiwa-peristiwa yang digambarkan di sekitar simbol itu mengambil warna yang emosional. Karena itu, sistem media massa yang terkendali merupakan sarana kuat dalam membentuk keyakinankeyakinan politik.

Kontak-kontak Langsung, Tidak peduli betapa positif pandangan terhadap sistem politik yang telah ditanamkam oleh keluarga atau sekolah, tetapi bila seseorang diabaikan oleh partainya, ditipu oleh polisi, kelaparan tanpa ditolong, dan dipaksa masuk wajib militer, pandangannya terhadap dunia politik sangat mungkin berubah. Partai politik, kampanye pemilihan umum, krisis-krisis politik luar negeri dan perang, dan daya tanggap badanbadan pemerintah terhadap tuntutan-tuntutan individu dan kelompokkelompok dapat mempengaruhi kesetiaan dan kesediaan mereka untuk mematuhi hukum.

\section{B. BUDAYA POLITIK}

Kebudayaan politik termasuk kajian dari ilmu politik. Banyak sarjana ilmu politik yang telah berupaya merumuskan makna budaya politik. Pendapat mereka tentang budaya politik terangkum dalam (Sri Jutmini dan Winarno : 2007), adalah sebagai berikut :

\section{a. Gabriel Almond dan Sidney Verba}

Budaya politik mengacu pada sikap orientasi yang khas warga negara terhadap sistem politik dan bagian-bagiannya dan sikap terhadap peranan warga negara dalam sistem itu. 


\section{b. Kay Lawson}

Budaya politik adalah terdapatnya satu perangkat yang meliputi seluruh nilai-nilai politik yang terdapat di seluruh bangsa.

\section{c. Alan R. Ball}

Budaya politik adalah susunan yang terdiri atas sikap, kepercayaan, emosi dan nilai-nilai masyarakat yang berhubungan dengan sistem politik dan isu-isu politik.

\section{d. Austin Ranney}

Budaya politik adalah seperangkat pandangan-pandangan tentang politik dan pemerintahan yang dipegang secara bersama, sebuah orientasi terhadap objek-objek politik.

Berdasar berbagai pendapat di atas dapat disimpulkan tentang budaya politik adalah sebagai berikut

a. Budaya politik dapat saja berupa perilaku aktual warga negara yang seperti tindakan, tetapi juga menekankan pada perilaku non-aktual yang berupa orientasi, seperti pengetahuan, sikap nilai, kepercayaan, dan penilaian warga negara terhadap suatu objek politik.

b. Hal-hal yang diorientasikan dalam budaya politik adalah sistem politik. Objek pembicaraan warga negara adalah kehidupan politik pada umumnya.

c. Budaya politik menggambarkan orientasi politik warga negara dalam jumlah besar, tetapi kadangkala juga perseorangan.

Kalau kita mengacu pada pendapat Gabriel Almond dan Sidney Verba di atas, maka dapat ditarik kesimpulan bahwa pada hakikatnya budaya politik mencakup dua hal, yaitu :

a. orientasi warga negara terhadap objek politik, dan

b. Sikap warga negara terhadap peranannya sendiri dalam sistem politik. 


\section{Orientasi Politik dan Objek Politik}

Salah satu makna dari budaya politik adalah orientasi warga negara terhadap subjek politik. Apa itu orientasi warga negara dan apa itu objek politik?

Kata "orientasi" bermakna luas meliputi melihat, mengenal, pandangan, pendapat, sikap, penilaian, pengetahuan, kepercayaan, keyakinan, dan lainlain. Oleh karena itu, orientasi warga negara meliputi tiga komponen orientasi yaitu : koginitif, afektif, dan evaluatif.

a. Orientasi kognitif yaitu, orientasi warga negara yang sifatnya kognitif atau pengetahuan seperti pengetahuan, wawasan, kepercayaan dan keyakinan warga negara terhadap suatu objek politik.

b. Orientasi afektif yaitu, orientasi warga negara yang sifatnya afektif atau sikap, seperti sikap-sikap, nilai-nilai, dan perasaan warga negara terhadap objek politik.

c. Orientasi evaluatif yaitu, orientasi warga negara yang sifatnya evaluatif atau penilaian, seperti pendapat dan penilaian warga negara terhadap suatu objek politik.

Objek politik adalah hal yang dijadikan sasaran dari orientasi politik warga negara. Objek politik yang dijadikan sasaran orientasi itu meliputi tiga hal sebagai berikut :

a. Objek politik umum atau sistem politik secara keseluruhan meliputi sejarah bangsa, simbol negara, wilayah negara, kekuasaan negara, konstitusi negara, lembaga-lembaga negara, pimpinan negara dan hal lain dalam politik yang sifatnya umum.

b. Objek politik input, yaitu lembaga atau pranata politik yang termasuk proses input dalam sistem politik. Lembaga yang termasuk dalam kategori objek politik input ini seperti partai politik, kelompok kepentingan, organisasi masyarakat, pers, dukungan dan tuntutan.

c. Objek politik output yaitu, lembaga atau pranata politik yang termasuk proses output dalam sistem politik. Lembaga yang termasuk dalam 
kategori objek politik output ini seperti birokrasi, lembaga peradilan, kebijakan, keputusan, undang-undang, dan peraturan.

Berdasarkan uraian di atas kita dapat mengatakan bahwa orientasi warga negara terhadap objek politik merupakan serangkaian pengetahuan, sikap, dan penilaian warga negara terhadap objek poltik, baik objek politik secara umum, objek politik input, maupun objek politik dalam proses output di dalam sistem politik. Meskipun komponen orientasi politik dapat dipisahpisahkan, akan tetapi dalam kenyataannya ketiga komponen orientasi politik tersebut tidak dapat berdiri sendiri. Ketiga komponen itu saling berkaitan, saling berhubungan, dan saling mempengaruhi (Sri Jutmini dan Winarno 2007 : 7). Lebih jauh Sri Jutmini dan Winarno memberikan contoh : "seorang warga negara diminta untuk menilai seorang pemimpin negara maka jawaban warga negara tersebut akan dipengaruhi oleh pengetahuannya terhadap pemimpin itu dan sikapnya sendiri terhadap pemimpin tersebut.

Sikap warga negara terhadap peranannya sebagai subjek politik adalah sikap individu terhadap partisipasinya sendiri dalam sistem politik. Warga negara sendiri dalam kehidupan bernegara memiliki peranan, tugas, hak, dan kewajiban-kewajiban tertentu. Sebagai warga negara, dia dapat mempertanyakan kepada diri sendiri apakah merasa memiliki dan mampu menjalankan seluruh peranan ataukah dia merasa tidak memiliki dan tidak mampu menjalankan peranan tersebut dalam kehidupan politik. Dengan demikian pribadinya sendiri sebagai warga negara dijadikan sasaran sikap dan orientasi dan pada saat itu ia merupakan suatu objek politik. Orientasi warga negara terhadap objek politik dapat menghasilkan dua orientasi yang berbeda yaitu : orientasi yang loyal atau setia terhadap sistem politik (alliegensi), dan orientasi yang terasing atau tersisihkan dari sistem politik (allienasi). Di antara dua orientasi tersebut terdapat orientasi apatis (apathy), yaitu seseorang tidak mau tahu, bersikap acuh atau masa bodoh terhadap objek politik. Dengan demikian sikap warga negara terhadap peranannya 
dalam sistem politik menghasilkan dua orientasi yang berbeda, yaitu orientasi yang partisipan atau aktif dan orientasi yang pasif.

\section{Tipe-tipe Budaya Politik}

Orientasi warga negara terhadap sistem atau objek politik berbedabeda dan beragam. Berdasarkan hal ini maka terdapat variasi budaya politik. Menurut Gabriel Almond dan Sidney Verba dalam (Sri Jutmini dan Winarno : 2007 : 8), mengklasifikasikan budaya politik menjadi tiga kebudayaan politik yaitu :

a. Budaya politik parokial;

b. Budaya politik subjek;

c. Budaya politik partisipan.

Ukuran yang digunakan untuk membedakan ketiga jenis budaya politik tersebut adalah derajat orientasi warga negara terhadap objek politiknya. Dengan adanya perbedaan orientasi warga negara terhadap objek politik memunculkan tiga budaya politik yang berbeda pula. Orientasi yang rendah terhadap objek politik dilambangkan dengan angka nol, sedangkan orientasi yang tinggi terhadap objek politik dilambangkan dengan angka satu. Secara skematis, ketiga budaya politik tersebut digambarkan sebagai berikut :

Tipe Budaya Politik

\begin{tabular}{|l|l|l|l|l|}
\hline \multirow{2}{*}{$\begin{array}{l}\text { Tipe } \\
\text { Budaya } \\
\text { Politik }\end{array}$} & \multicolumn{2}{|l|}{ Objek Politik } & Sikap \\
\cline { 2 - 5 } & Umum & Input & Out Put & $\begin{array}{l}\text { Terhadap } \\
\text { Pribadi }\end{array}$ \\
\hline Parokial & 0 & 0 & 0 & 0 \\
\hline Subjek & 1 & 0 & 1 & 0 \\
\hline Partisipan & 1 & 1 & 1 & 1 \\
\hline
\end{tabular}

\section{a. Budaya Politik Parokial}

Dalam budaya politik parokial, orientasi politik warga negara terhadap keseluruhan objek politik, baik umum, input, dan output, serta pribadinya 
mendekati nol atau dapat dikatakan rendah. Berdasarkan hal ini maka ciriciri budaya politik parokial adalah sebagai berikut :

1. Warga negara cenderung tidak menaruh minat terhadap objek-objek politik yang luas, kecuali yang ada disekitarnya.

2. Warga tidak banyak berharap atau tidak memiliki harapan-harapan tertentu dari sistem politik di mana ia berada.

3. Kesadaran anggota masyarakat akan adanya pusat kewenangan atau kekuasaan dalam masyarakatnya.

4. Berlangsung dalam masyarakat yang tradisional dan sederhana.

5. Belum adanya peran-peran politik yang khusus, peran politik dilakukan serempak bersamaan dengan peran ekonomi, keagamaan dan lain-lain.

6. Berkaitan dengan di atas maka pelaku politik tidak hanya menjalankan peran politik tetapi berperan lain di masyarakat tersebut, contohnya : seorang kepala suku tidak hanya memimpin suku, tetapi juga sekaligus penguasa ekonomi, pemimpin spiritual dan panglima perang.

\section{b. Budaya Politik Subjek}

Dalam budaya politik subjek, orientasi politik warga negara terhadap objek politik umum dan objek politik output adalah mendekati satu atau dapat dikatakan orientasinya tinggi. Sebaliknya orientasi warga negara terhadap objek politik input dan peranannya sendiri adalah mendekati nol atau dapat dikatakan rendah. Berdasarkan hal tersebut berikut ini adalah ciri-ciri budaya politik subjek :

1. Warga negara menaruh kesadaran, minat, dan perhatian terhadap sistem politik pada umumnya dan terutama pada objek politik output, sedangkan kesadarannya terhadap input dan kesadarannya sebagai aktor politik rendah.

2. Warga negara menyadari sepenuhnya akan otoritas pemerintah

3. Mereka tidak berdaya mempengaruhi, bahkan tunduk dan patuh saja terhadap segala kebijakan dan keputusan yang ada di masyarakatnya. 
4. Sikapnya sebagai aktor politik adalah pasif, artinya tidak mampu berbuat banyak untuk berpartisipasi dalam kehidupan politik.

5. Tidak banyak memberi masukan dan tuntutan kepada pemerintah, tetapi cukup puas untuk menerima apa yang berasal dari pemerintah.

\section{c. Budaya Politik Partisipan}

Dalam budaya politik partisipan, orientasi politik warga negara terhadap keseluruhan objek politik, baik umum, input, output, maupun pribadinya mendekati satu atau dapat dikatakan tinggi. Berdasarkan hal ini maka ciri-ciri budaya politik partisipasi adalah sebagai berikut :

1. Anggota masyarakat sangat partisipatif terhadap semua objek politik, baik menerima maupun menolak suatu objek politik.

2. Kesadaran bahwa mereka adalah warga negara yang aktif dan berperan sebagai aktivis.

3. Warga negara menyadari akan hak dan tanggungjawabnya dan mampu mempergunakan hak itu serta menanggung kewajibannya.

4. Tidak menerima begitu saja keadaan, tunduk kepada keadaan, berdisiplin, tetapi dapat menilai dengan penuh kesadaran semua objek politik, baik keseluruhan, input, output, ataupun posisi dirinya sendiri.

5. Kehidupan politik dianggap sebagai sarana transaksi seperti halnya penjual dan pembeli. Warga negara dapat menerima berdasarkan kesadarannya, tetapi juga mampu menolak berdasarkan penilaiannya.

Lebih jauh menurut Gabriel Almond dan Sidney Verba, ketiga budaya politik di atas sebangun dan selaras dengan budaya politiknya, yaitu sebagai berikut :

a. Budaya politik parokial sebangun dengan sistem politik tradisional.

b. Budaya politik subjek sebangun dengan sistem politik otoritarian.

c. Budaya politik partisipan sebangun dengan sistem politik demokrasi.

Keserasian antara budaya politik dengan sistem poltiknya akan membentuk kematangan budaya politik. Dengan demikian, kematangan 
budaya politik bangsa akan tergantung sejauh mana keserasian antara budaya politik dengan sistem politik dari bangsa yang bersangkutan. Semakin serasi antara struktur atau sistem politik dengan aspek-aspek budaya bangsa semakin matang pula budaya politiknya.

Akan tetapi dalam kenyataannya sulit dijumpai masyarakat atau bangsa yang hanya berbudaya politik parokial, subjek atau partisipan semata. Kenyataan umumnya satu bangsa memiliki budaya politik campuran di antara ketiga tipe kebudayaan tersebut di atas. Selanjutnya lagi Gabriel Almond dan Sidney Verba mengemukakan adanya tiga budaya politik campuran yaitu sebagai berikut :

\section{Budaya Politik Parokial Subjek}

Masa peralihan dari budaya politik parokial menuju budaya politik subjek, sebagian masyarakat masih menaruh perhatian kepada hal-hal yang bersifat tradisional, sebagiannya lagi menolak dan mengarahkan perhatiannya kepada pemerintahan terpusat (otoritarian)

\section{Budaya Politik Subjek - Partisipan}

Masa peralihan dari budaya politik subjek menuju budaya politik partisipan, sebagian masyarakat sudah berorientasi pada input (aktif dalam memberi masukan) dan menyadari sebagai warga negara aktif, namun sebagian lagi masih berorientasi pada struktur pemerintahan yang otoriter, yaitu taat pada keputusan dan pasif sebagai warga negara.

\section{Budaya Politik Parokial - Partisipan.}

Berada pada masyarakat yang masih memiliki budaya politik parokial, tetapi sistem dan norma-norma politik yang dikembangkan menuntut masyarakatnya untuk berbudaya politik partisipan.

\section{Budaya Politik Kewarganegaraan (civics culture)}

Di samping ketiga budaya politik campuran tersebut di atas terdapat juga budaya politik kewarganegaraan yang merupakan campuran atau 
gabungan ciri-ciri yang ada pada ketiga budaya politik sebelumnya. Dalam budaya politik kewarganegaraan, orientasi politiknya pada budaya politik partisipan dikombinasikan secara seimbang dengan orientasi pada budaya politik subjek dan budaya politik parokial.

\section{B. PARTISIPASI POLITIK}

Parisipasi politik adalah bentuk-bentuk keikutsertaan warga negara dalam aktivitas-aktivitas politik dalam suatu negara. Bentuk-bentuk partisipasi tersebut dapat berupa keikutsertaan warga negara dalam proses pembuatan keputusan politik, ikut memberikan suara pada pemilihan umum, dan ikut menduduki jabatan-jabatan baik politik maupun pemerintahan.

Kecendrungan warga negara untuk ikut berpartisipasi politik dalam bentuknya yang lebih luas bermula pada masa renaissance dan reformasi abad ke-15 sampai abad ke-17 dan abad ke-18 dan abad ke-19. Akan tetapi bagaimana cara berbagai golongan dalam masyarakat menuntut hak mereka untuk ikut berpartisipasi lebih luas dalam pembuatan keputusan politik sangat berbeda di berbagai negara. Menurut Myron Weiner dalam (Mas'oed dan MacAndrews : 2000 : 45), bahwa paling tidak terdapat lima hal yang menyebabkan timbulnya gerakan ke arah partisipasi yang lebih luas dalam proses politik, yaitu :

\section{Penyebab Partisipasi}

\section{a. Modernisasi}

Modernisasi menyebabkan indsustrialisasi, urbanisasi, penyebaran kepandaian baca-tulis, perbaikan pendidikan, teknologi media massa, serta komersialisasi pertanian. Dari kesemuanya itu membuat sebagian besar warga negara merasa mampu mempengaruhi nasib mereka sendiri, dan mereka banyak menuntut keterlibatan dalam politik.

b. Perubahan-perubahan kelas sosial

Selama proses modernisasi dan industrialisasi dimulai, lapangan kerja semakin terspesialisasi, lapangan kerja semakin banyak, terbentuk kelas- 
kelas baru dalam masyarakat dan kelas menengah semakin meluas. Masalah tentang siapa yang berhak berpartisipasi dalam pembuatan keputusan politik menjadi penting dan mengakibatkan perubahan-perubahan dalam pola-pola partisipasi.

c. Pengaruh kaum intelektual dan komunikasi massa modern

Kaum intelektual seperti sarjana, pengarang, wartawan sering mengemukakan ide-ide kepada warga negara untuk membangkitkan tuntutan akan partisipasi massa yang lebih luas dalam pembuatan keputusan politik. Begitu pula sistem transportasi dan komunikasi modern akan memudahkan dan mempercepat penyebaran ide-ide baru.

d. Konflik di antara pemimpin politik

Ketika terjadi konflik di antara pemimpin politik, maka strategi yang sering digunakan oleh para pemimpin politik adalah melibatkan kelompokkelompok politik yang ada dan mencari dukungan rakyat.

e. Keterlibatan pemerintah yang lebih luas dalam kehidupan sosial.

Meningkatnya peranan pemerintah dalam kehidupan sosial warga negara seperti ekonomi, kebudayaan, pendidikan, tentunya akan menimbulkan dampak yang lebih luas. Dampak tersebut dapat menguntungkan warga negara ataupun merugikannya. Perjuangan untuk menuntut hak secara berkelompok dalam bentuk seperti demonstrasi bagi masyarakat yang dirugikan akan memberikan kesempatan untuk berperan serta mempengaruhi suatu kebijakan pemerintah.

\section{Bentuk-bentuk Partisipasi Politik}

Tabel berikut ini menunjukkan bentuk-bentuk partisipasi politik yang terjadi di berbagai negara dan berbagai waktu. Kegiatan politik konvensional adalah bentuk-bentuk partisipasi politik yang normal di negara demokrasi modern. Sedangkan bentuk-bentuk partisipasi yang non-konvensional termasuk beberapa yang mungkin legal (seperti petisi) maupun yang illegal, yang penuh kekerasan, dan bersifat revolusioner. Bentuk-bentuk dan frekuensi 
partisipasi politik dapat dipakai sebagai alat ukur untuk menilai stabilitas sistem politik, dan kepuasan atau ketidakpuasan warga negara. Berikut ini adalah tabel bentuk-bentuk partisipasi politik.

\begin{tabular}{|l|l|}
\hline Konvensional & Non-Konvensional \\
\hline -Pemberian suara (voting) & -Pengajuan petisi \\
-Diskusi politik & -Demonstrasi \\
-Kegiatan kampanye & -Konfrontasi \\
-Membentuk dan bergabung dalam & -Mogok \\
kelompok kepentingan & -Tindak kekerasan politik terhadap \\
-Komunikasi individual dengan & harta benda (pengrusakan, \\
pejabat politik dan administratif & pembakaran, bom) politik \\
& -Tindakan kekerasan (penculikan, \\
& terhadap manusia \\
& pembunuhan) \\
& -Perang gerilya, revolusi. \\
\hline
\end{tabular}

a. Pemberian suara (Voting)

Pemberian suara merupakan bentuk partisipasi politik aktif yang paling luas tersebar. Dewasa ini perkembangan pemberian suara melalui pemilihan umum terdapat hampir di semua sistem politik, baik yang demokrat maupun yang otoriter.

Pemilihan umum di negara-negara dan berpartai tunggal hanyalah sekadar alat bagi penguasa dari pada alat untuk memilih siapa yang seharusnya menjalankan kekuasaan tersebut. pemilihan umum di negaranegara berpartai tunggal tidak dimaksudkan untuk memberi kesempatan pada rakyat dalam rangka mempengaruhi kebijaksanaan pemerintah, akan tetapi hanyalah sekadar memberi kesempatan kepada elit politik yang berkuasa untuk berpropaganda dan sekaligus memobilisasi rakyat. Pemberian suara merupakan tindakan untuk memeperoleh dukungan rakyat terhadap sistem politik dan elit yang berkuasa. Penolakan untuk ikut mermberi suara dianggap sebagai penolakan secara diam-diam. 
b. Demonstrasi, Protes, dan Tindakan Kekerasan

Ted Robert Gurr dalam (Mas'oed dan MacAndrews : 2000 : 48), mengatakan bahwa tindakan kekerasan politik bersifat episodik dalam sejarah sebagian besar masyarakat politik dan bersifat kronis dalam beberapa masyarakat. Tindakan kekerasan tersebut memperlihatkan bentuknya seperti kerusuhan-kerusuhan berdarah, pembunuhan, dan kudeta, serta protes-protes dalam bentuk unjuk rasa.

Tindakan kekerasan yang lebih umum adalah kudeta, di mana sekelompok kecil konspirator - yang biasanya dari kalangan militer menggulingkan pemerintah serta menggatinya dengan suatu kelompok penguasa baru atau bahkan mungkin menciptakan rezim baru. Kebanyakan dari kudeta-kudeta ini relatif tidak berdarah, akan tetapi kebanyakan yang lain adalah kudeta berdarah.

Bentuk partisipasi politik yang berwujud demonstrasi, protes, dan tindakan kekerasan ini biasanya dipergunakan oleh orang untuk mempengaruhi kehidupan politik dan kebijakan pemerintah bila bentukbentuk aktivitas lain tidak bisa lagi dilakukan atau tidak efektif. Frekuensi penggunaannya juga berbeda-beda menurut situasi dan masyarakat. Dalam beberapa masyarakat politik tindakan demonstrasi, protes, dan tindakan kekerasan jarang terjadi oleh karena sistem politiknya cukup tanggap terhadap kebutuhan dan tuntutan warganya, akan tetapi dalam masyarakat yang lain, tindakan-tindakan semacam itu mungkin merupakan aktivitas politik yang rutin disebabkan oleh karena salah satunya adalah pemerintah tidak tanggap terhadap tuntutan warga negara. 


\section{BAB IV}

\section{PEMERINTAHAN DAN BIROKRASI}

\section{A. PEMERINTAHAN}

\section{Konsep Dasar Pemerintahan}

Pemikiran tentang bentuk-bentuk pemerintahan sudah tua usianya. Ilmu politik dimulai dengan klasifikasi bentuk-bentuk pemerintah dan sampai dewasa ini masalah tersebut masih tetap menarik perhatian sarjana-sarjana ilmu politik.

Herodotus pernah melukiskan suatu percakapan antara tujuh saudagar Bangsa Parsi yang harus mengadakan pilihan antara bentuk-bentuk pemerintah, yaitu antara bentuk kerajaan, oligarkhi atau demokrasi. Menurut Herodotus, saudagar-saudagar Parsi tersebut memilih kerajaan sebagai bentuk pemerintah yang terbaik.

Namun, Plato kemudian Aristoteles mengadakan peneyelidikan tentang bentuk-pemerintah secara mendalam dan sistematis. Menurut Isjwara (1999 : 185), Dalam kepustakaan ilmu politik dikenal adanya dua klasifikasi tradisionil dari bentuk-bentuk pemerintah. Pertama dan tertua adalah klasifikasi tri-bagian (tri-partite classification) dan kedua adalah klasifikasi dua-bagian (bi-partite classification).

Plato adalah salah seorang sarjana yang pertama-tama mengadakan pembahasan yang mendalam dan sistematis tentang bentuk-bentuk pemerintah. Plato membahas masalah itu dalam bab VIII dan IX dari "Republik"nya. Klasifikasi Plato tentang bentuk pemerintahan adalah sebagai berikut : 
Klasifikasi Bentuk-bentuk Pemerintah Menurut Plato

\begin{tabular}{|l|l|}
\hline Bentuk pemerintah yang terbaik & Bentuk pemerintah yang merosot \\
\hline 1. Kerajaan & 1. Tirani \\
2. Aristokrasi & 2. Oligarkhi \\
3. Demokrasi & 3. Mobokrasi \\
\hline
\end{tabular}

Sejalan dengan bentuk-bentuk pemerintahan yang baik dan yang merosot itu ada pula warga negara yang baik dan ada yang buruk yang menempati jabatan-jabatan yang tertinggi dalam negara itu.

Jika Plato memberikan uraian-uraian yang filosofis-idealistis tentang bentuk bentuk pemerintah, maka Aristoteles murid Plato sebaliknya mengemukakan masalah bentuk pemerintah itu secara empiris induktif. Aristoteles mengupas masalah bentuk-bentuk pemerintah setelah ia menyelidiki kurang lebih 158 konstitusi negara-negara kota Yunani yang pernah ada dan yang masih ada dalam zamannya. Dari penyelidikanpenyelidikan konstitusionil itu hanya satu yang dapat diketemukan kembali, yaitu penyelidikan tentang konstitusi kota Athena. Atas dasar penyelidikan yang empiris ini Aristoteles kemudian membuat klasifikasi bentuk-bentuk pemerintah atas dasar dua kriteria : secara kuantitatif, yaitu berdasarkan jumlah orang orang yang memegang kekuasaan dalam suatu negara. Dan secara kualitatif, yaitu berdasarkan pelaksanaan kesejahteraan umum oleh penguasa-penguasa negara itu. Berikut ini adalah tabel yang menunjuk hal tersebut di atas :

\begin{tabular}{|l|l|l|}
\hline Bentuk Pemerintah & Bentuk-bentuk biasa & Bentuk merosot dalam \\
& dalam mana penguasa- & mana penguasa \\
& penguasa berusaha & berusaha mewujudkan \\
mewujudkan & kepentingan dirinya \\
& kesejahteraan umum & sendiri/gol. \\
\hline Pemerintah seorang & Monarkhi & Tirani \\
\hline
\end{tabular}




\begin{tabular}{|l|l|l|}
\hline $\begin{array}{l}\text { Pemerintah beberapa } \\
\text { orang }\end{array}$ & Aristokrasi & Oligarkhi \\
\hline $\begin{array}{l}\text { Pemerintah semua } \\
\text { warga negara }\end{array}$ & Polity & Demokrasi \\
\hline
\end{tabular}

Monarchy berasal dari kata-kata Yunani monos yang berarti satu dan archein yang berarti menguasai, memerintah, kerajaan adalah pemerintahan dalam hal mana seluruh kekuasan dipegang oleh seorang yang berusaha mewujudkan kesejahteraan umum.

Tirani ialah bentuk pemerintahan di mana kekuasaan juga berpusat pada satu orang, tetapi yang berusaha mewujudkan kepentingan dirinya sendiri dan tidak mengindahkan kesejahteraan umum.

Aristokrasi berasal dari kata aristoi, yaitu kaum bangsawan atau cendekiawan dan kratein yang berarti kekuasaan. Ialah bentuk pemerintah dalam mana kekuasaan negara berpusat pada beberapa orang yang berusaha mewujudkan kesejahteraan umum. Bentuk ini disebut aristokrasi karena orang-orang yang berkuasa adalah orang-orang yang paling baik dan senantiasa mewujudkan kesejahteraan umum. Bentuk merosotnya ialah oligarchi yang berarti oligoi atau beberapa, dan archein yakni pemerintahan beberapa orang yang mengutamakan kepentingan golongan sendiri.

Polity ialah bentuk pemerintahan dalam mana seluruh warga negara turut serta mengatur negara dengan maksud mewujudkan kesejahteraan umum. Bentuk ini ditafsirkan oleh Garner dalam (Isjwara : 1999 : 185), sebagai bentuk pemerintahan yang menyerupai bentuk pemerintahan demokrasi konstitusionil dewasa ini. Sedangkan menurut McIver sebagai bentuk pemerintahan di mana golongan menengah yang memegang kekuasaan pemerintahan.

Demokrasi berasal dari kata demos yang berarti rakyat, dan kratein berarti pemerintahan, yang ekstrim disebut sebagai bentuk merosot dari polity. Aristoteles menganggap demokrasi sebagai bentuk merosot, karena 
berdasarkan pengalamannya sendiri penguasa-penguasa di negara negara kota yang demokratis dari zamannya seperti Athena adalah teramat korupsi.

Aristoteles menganggap demokrasi sebagai bentuk pemerintah yang buruk, pemerosotan bentuk pemerintahan polity. Dalam hal ini Aristoteles juga berbeda dengan Plato yang menganggap demokrasi sebagai bentuk pemerintah yang paling buruk dari pada bentuk-bentuk pemerintah yang baik. Aristoteles menganggap demokrasi sebagai bentuk pemerintah yang merosot, karena negara yang berbentuk demokratis yang berkuasa adalah orang-orang miskin, serakah dan tidak beradab. Mereka yang pertama-tama memenuhi kebutuhannya sendiri dengan tidak mengindahkan kesejahteraan umum.

Cicero (106-43 SM), seorang filosof Romawi menggolongan bentukbentuk pemerintahan berdasarkan prinsip yang dinamakannya concilium. Penggolongannya adalah sebagai berikut : apabila concillium itu dipegang oleh seorang, maka bentuk pemerintahan itu adalah kerajaan ; apabila dipegang oleh beberapa orang bentuk pemerintahanya adalah aristokrasi, apabila dipegang oleh seluruh rakyat bentuk adalah demokrasi. Cicero juga menerima adanya bentuk pemerintah yang merosot dari pemerintah yang baik. Dominus atau despot adalah bentuk merosot dari kerajaan dan Facto, turba et confucio adalah bentuk-bentuk merosot yang dihasilkan oleh aristokrasi dan demokrasi.

Demikian pula Hobbes, menerima penggolongan tri-bagian dari Aristoteles. Bagi Hobbes kriterium yang membedakan satu pemerintah dari pemerintah lainnya ialah perbedaan dalam letak kedaulatan. Apabila kedaulatan terletak pada satu orang bentuk pemerintah itu ialah kerajaan, apabila pada semua warga negara, maka didapati demokrasi, dan apabila beberapa orang yang berdaulat maka bentuknya adalah aristokrasi. Dari semua jenis bentuk pemerintahan itu Hobbes mengutamakan kerajaan, teristimewa kerajaan mutlak. Bagi Hobbes tidak mengenal bentuk-bentuk merosot dari pemerintahan yang baik seperti klasifikasi Aristoteles, menurutnya tirani, oligarkhi, dan anarkhi hanya sebutan yang dipergunakan 
bagi mereka yang tidak puas dengan bentuk-bentuk kerajaan, aristokrasi dan demokrasi itu.

John Locke juga mengemukakan teori bentuk-bentuk pemerintah yang berpangkal dari tri-bagian dari Aristoteles. Locke membedakan bentuk-bentuk pemerintahan atas kriteria wewenang membuat hukum, jadi perbedaan yang didasarkan atas letak kekuasaan legislatif. Berdasarkan kriteria tersebut Locke membedakan tiga jenis bentuk-bentuk pemerintah yaitu demokrasi, oligarkhi, dan monarkhi. Kerajaan dapat berbentuk turun-temurun, apabila yang dapat menjadi raja hanya seorang dan keturunannya saja, ataukah kerajaan elektif atau pilihan, apabila rakyat setelah raja itu meninggal, dapat menentukan penggatinya.

Montesqueiu (1669-1785), juga mengikuti klasifikasi Aristoteles. Ia mendalilkan adanya tiga macam bentuk pemerintah yaitu republik dengan dua bentukan tambahan demokrasi dan aristokrasi serta kerajaan dan despotisme. Dengan bentuk pemerintah republik dimaksudkan pemerintahan di mana seluruh rakyat (demokrasi) atau sebagian rakyat (aristokrasi) memegang kekuasaan tertinggi. Kerajaan adalah bentuk pemerintahan di mana satu orang memerintah, tetapi memerintah menurut undang-undang yang telah ditentukan. Despotisme adalah bentuk pemerintah di mana satu orang memerintah tanpa undang-undang dan peraturan menurut kehendak dan kesukaannya. Despotisme adalah pemerintahan yang didasarkan atas kesewenang-wenangan. Ketiga macam bentuk-bentuk pemerintahan ini masing-masing didasarkan atas asas khusus, yaitu repuplik didasarkan atas asas kebaikan warga negara yaitu demokrasi berdasarkan cinta tanah air dan persamaan, lalu aristokrasi didasarkan atas asas modernisasi, sedangkan kerajaan berdasarkan atas asas kehormatan, dan despotisme didasarkan atas asas ketakutan.

Akan tetapi, disamping penerimaan tri-bagian Aristoteles itu ada pula yang menolaknya sebagai tidak mencukupi dan tidak sesuai lagi dengan perkembangan praktek-praktek bentuk-bentuk pemerintahan modern. 
Di samping klasifikasi tri-bagian, bentuk-bentuk pemerintahan dapat juga digolongkan dalam klasifikasi dua-bagian (two-partite classification) yaitu dalam bentuk kerajaan dan republik. Pembagian dalam dua jenis bentuk pemerintahan ini dimulai oleh Machiavelli yang memulai halaman pertama dari bukunya yang termasyhur "The Prince" dengan kalimat...semua pemerintahan dan bentuk penguasaan yang pernah ada yang kini menguasai manusia dan yang pernah menguasai manusia adalah atau republik atau kerajaan... Bagi Machiavelli tidak ada bentuk-bentuk pemerintahan selain kerajaan dan republik. Dalam "the prince" itu, Machiavelli menganggap bentuk kerajaan sebagai bentuk pemerintahan yang terbaik. Kedudukan raja dapat turun-temurun atau dapat didasarkan atas pemilihan.

\section{Birokrasi}

Secara etimologis, birokrasi berasal dari kata biro (bureau) yang berarti kantor atau dinas, dan kata krasi (cracy, kratie) yang berarti pemerintahan. Dengan demikian birokrasi berarti dinas pemerintahan. Secara tipologik (tipe ideal), Max Weber dalam (Surbakti : 1999 : 183), mendeskripsikan sejumlah karakteristik birokrasi sebagai berikut : pertama, dalam organisasi terdapat pembagian kerja dengan spesialisasi peranan yang jelas. Pembagian kerja yang jelas dan terinci ini akan membuka kesempatan untuk hanya merekrut para pegawai yang ahli dalam bidangnya dan memungkinkan masing-masing pegawai sebagai pihak yang bertanggungjawab dalam pelaksanaan tugasnya.

Kedua, organisasi jabatan ini mengikuti prinsip hirarki. Artinya, jabatan yang lebih rendah berada dalam kontrol dan pengawasan jabatan yang lebih tinggi. Setiap pejabat dalam hirarki administrasi ini mempertanggungjawabkan kepada atasannya tidak saja setiap keputusan dan tindakan yang diambilnya sendiri, tetapi juga setiap keputusan dan tindakan yang diambil bawahannya. Untuk dapat mempertanggungjawabkan tindakan bawahan, pejabat memiliki kewenangan untuk memberikan pengarahan kepada bawahan dan pejabat bawahan berkewajiban menaati pejabat atasan. 
Ketiga, kegiatan organisasi jabatan ini dilakukan berdasarkan sistem aturan abstrak yang konsisten dan terdiri atas penerapan aturan-aturan ini ke dalam kasus-kasus yang khusus. Sistem standar ini dirancang untuk menjamin keseragaman tidak hanya dalam pelaksanaan setiap tugas, terlepas dari berapapun jumlah personil yang terlibat di dalamnya, tetapi juga dalam koordinasi berbagai tugas. Aturan dan pengaturan yang eksplisit membatasi kewajiban masing-masing anggota organisasi dan hubungan-hubungan di antara mereka.

Keempat, setiap pejabat melaksanakan tugasnya dalam semangat kerja yang tinggi dan hubungan yang formal dan impersonal, yaitu tanpa perasaan benci ataupun simpati, dan karena itu tanpa afeksi atau antusiasme, artinya pejabat dalam melaksanakan tugasnya tanpa intervensi (dicampuri) dengan kepentingan personal. Perilaku diskriminatif dan ketidakefisienan hanya dapat dihilangkan apabila pertimbangan-pertimbangan pribadi tidak dilibatkan dalam pelaksanaan tugas operasional organisasi. Dalam hal ini, terdapat satu kritik terhadap Weber, yaitu hubungan-hubungan informasi yang berlangsung di antara anggotanya justru mendorong pelaksanaan kegiatan organisasi formal.

Kelima, setiap pegawai dalam organisasi ini direkrut menurut prinsipi kualifikasi teknis (merit sistem), digaji dan dipensiunkan menurut pangkat dan kemampuan, dan dipromosikan menurut asas kesenioran atau kemampuan, atau keduanya. Prinsip-prinsip ini akan mendorong pengembangan kesetiaan kepada organisasi dan pengembangan semangat korps di antara para anggotanya. Hal-hal inilah yang akan mendorong para pegawai untuk memajukan tujuan-tujuan organisasi.

Keenam, organisasi administrasi yang bertipe birokratis dari segi pandangan teknis murni cenderung lebih mampu mencapai tingkat efisiensi lebih tinggi. Oleh karena itu, birokrasi mengatasi masalah unik organisasi. Artinya, memaksimalkan koordinasi dan pengendalian sehingga akan tercapai tidak hanya efisiensi organisasi tetapi juga efisiensi produktif setiap pegawai. 
Seluruh karakteristik birokrasi itu akan menghasilkan suatu birokrasi yang tidak hanya superior dalam efektivitas, yaitu skala yang besar, tetapi juga superior dalam efisiensi.

Di samping fungsi birokrasi yang positif (efektif dan efisien) seperti yang disebutkan di atas, Weber juga menyebutkan fungsi negatif dari birokrasi. Pertama, birokrasi cenderung memonopoli informasi sehingga pihak luar tidak dapat mengetahui atas dasar apa keputusan itu diambil. Konsep "rahasia jabatan" merupakan penemuan unik birokrasi, dan tidak ada yang lebih dipertahankan secara fanatik oleh birokrasi selain rahasia jabatan tersebut. kedua, apabila sudah terlembaga, birokrasi merupakan salah satu struktur sosial yang paling sukar dihancurkan. Menghapuskan birokrasi merupakan pekerjaan yang sia-sia. Tidak mungkin mengelola suatu bangsanegara yang besar atau perusahaan swasta tanpa menggunakan spesialisasi dan keahlian yang dimiliki oleh birokrasi, pegawai dapat diganti tetapi seluruh pola administrasi yang konsisten dengan pola birokratis itu tidak mudah diubah. Ketiga, birokrasi yang sudah mapan cenderung bersifat mendua terhadap demokrasi. Pada satu pihak prinsip-prinsip persamaan di depan hukum yang melandasi kegiatan birokrasi (impersonal, sistem aturan yang homogen) mendukung pelaksanaan demokrasi, pada pihak lain birokrasi cenderung tidak tanggap terhadap pendapat umum.

Baik fungsi negatif maupun fungsi positif dari birokrasi dapat dipahami sebagai akibat dari prinsip-prinsip pengorganisasian yang dimaksudkan untuk mencapai koordinasi dan pengendalian. Pada dasarnya birokrasi merupakan aparat yang melaksanakan keputusan yang dibuat dan dijabarkan oleh pemerintah. Untuk itu birokrasi berkewajiban memberikan informasi dan sumber daya manusia (keahlian) kepada pemerintah selaku pembuat peraturan, sedangkan kepada masyarakat birokrasi tidak hanya memberikan pelayanan, tetapi juga menegakkan peraturan sesuai dengan kewenangan yang ada padanya. 
Sehubungan dengan tugas-tugas birokrasi ini dapat ditambahkan bahwa kenyataan menunjukkan birokrasi tidak hanya melaksanakan kebijakan umum, tetapi juga birokrasi yang pertama-tama mengusulkan kebijakan tersebut. berbeda dengan Weber yang memandang birokrasi sebagai netral dalam politik, dewasa ini kenyataan menunjukkan bahwa birokrasi memiliki pengaruh politik dan tindakannya ikut menentukan gerak-gerik pemerintahan.

Selain itu, birokrasi bahkan berkembang menjadi penguasa ketika peraturan diterapkan kepada masyarakat. Kedua hal yang disebutkan terakhir ini merupakan gejala atau karakteristik sistem politik yang disebut birokratik polity atau birokratis-otoriter.

\section{a. New Public Manajement.}

Pada awalnya birokrasi dimaksudkan untuk memfasilitasi pembengunan dengan menciptakan efisiensi organisasi secara maksimum. Selama tahun 1930-an birokrasi memainkan peran utama dalam pembangunan. Namun birokrasi yang semakin kuat tersebut kemudian menunjukkan kecendrungan-kecendrungan yang kuran baik, di antaranya birokrasi menjadi sangant sulit untuk ditembus, sentralistis, top down, dan hierarki yang sangat panjang. Birokrasi justru menyebabkan kelambanan, terlalu betele-tele, dan mematikan kreativitas. Birokrasi juga dipandang mengganggu mekanisme pasar dan menciptakan distorsi ekonomi (Mardiasmo : 2004 : 16). Pada akhirnya, birokrasi justru menyebabkan inefisiensi organisasi.

Lebih jauh Mardiasmo (2004 : 16), mengatakan bahwa, saat ini - ketika dunia dihadapkan pada ketidakpastian (turbulence and uncertainty), teknologi informasi yang semakin canggih, masyarakat yang semakin banyak menuntut (demanding community), dan persaingan yang semakin ketat, maka birokrasi yang seperti itu tidak akan dapat bekerja dengan baik. Untuk mengantisipasi era globalisasi dan masyarakat yang semakin cerdas (knowledge based society) 
birokrasi perlu melakukan perubahan menuju profesionalisme birokrasi dan lebih menekankan efisiensi.

Sejak pertengahan tahun 1980-an di Eropa dan Amerika terjadi perubahan manajemen sector public yang cukup drastis dari sistem manajemen tradisional yang terkesan kaku, birokratis, dan hirarkis menjadi model manajemen publik yang fleksibel dan lebih mengakomodasi pasar. Perubahan tersebut telah mengubah peran pemerintah terutama dalam hal hubungan antara pemerintah dan masyarakat. Paradigma baru manajemen sector publik tersebut kemudian dikenal dengan New Public Manajement.

New Public Manajement berfokus pada manajemen, penilaian kinerja, dan efisiensi. Bukan berorientasi pada kebijakan. Penggunaan paradigma New Public Manajement tersebut menimbulkan beberapa konsekuensi bagi pemerintah di antaranya adalah tuntutan untuk melakukan efisiensi, pemangkasan biaya (cost cutting), dan kompetisi tender (compulsory competitive tendering - CCT).

Pada dasarnya New Public Manajement merupakan konsep manajemen sektor publik yang berfokus pada perbaikan kinerja organisasi. Penerapan konsep tersebut akan berimplikasi pada perlunya dilakukan pada perubahan manajerial, terutama yang menyangkut perubahan personil dan struktur organisasi.

Sehubungan dengan hal tersebut di atastuntutan kebutuhan dan perubahan zaman maka Osborne dan Gaebler (1992), mengajukan suatu model pemerintahan yang dikenal dengan konsep "reinventing government". reinventing government merupakan persfektif baru bagi pemerintah. adalah sebagi berikut :

a. Pemerintahan Katalis : focus pada pemberian pengarahan bukan produksi pelayanan publik.

Pemerintah daerah harus menyediakan (providing) beragam pelayanan public, tetapi tidak harus terlibat secara langsung dengan proses produksinya (producing). Sebaliknya pemerintah daerah memfokuskan diri 
pada pemberian arahan, sedangkan produksi pelayanan public diserahkan kepada pihak swasta dan/atau sektor ketiga (lembaga swadaya masyarakat dan nonfrofit lainnya). Produksi pelayanan public oleh pemerintah daerah, harus dijadikan sebagai pengecualian. Dan bukan keharusan: pemerintah daerah hanya memperoduksi pelayanan public yang belum dapat dilakukan oleh pihak non government atau pihak swasta. Pada saat sekarang ini, telah banyak bentuk pelayanan public yang dapat diproduksi oleh sector swasta dan sector ketiga (LSM). Bahkan pada beberapa negara, penagihan pajak dan retribusi sudah lama dikelola oleh pihan bukan pemerintah.

b. Pemerintah Milik Masyarakat : memberi wewenang pada masyarakat dari pada melayani.

Pemerintah daerah sebaiknya memberikan wewenang kepada masyarakat sehingga mereka mampu menjadi masyarakat yang mampu menolong dirinya sendiri (community self-help). Misalnya, masalah keselamatan umum adalah juga merupakan tanggungjawab masyarakat, tidak hanya tugas kepolisian. Oleh karenanya kepolisian semestinya tidak hanya memperbanyak polisi untuk mewnanggapi peristiwa criminal, tetapi juga membantu warga untuk memecahkan masalah yang meyebabkan timbulnya tindakan criminal. Contoh lainnya adalah pemerintah mengembangkan usaha kecil, pemberian wewenang optimal kepada asosiasi pengusaha kecil untuk memmecahkan masalah yang mereka hadapi.

c. Pemerintah yang Kompetitif : memotivasi semangat kompetisi dalam pemberian pelayanan public. Kompetisi adalah satu-satunya cara untuk menghemat biaya sekaligus meningkatkan kualitas pelayanan. Dengan kompetisi, banyak pelayanan public yang dapat ditingkatkan kualitasnya tanpa harus memperbesar biaya. Perhatikan pada pelayanan pos oleh negara yang sifatnya monopoli - dengan memberikan kesempatan kompetisi yang sehat pada sector pelayanan titipan kilat akan menjadi 
lebih cepat dari pada kualitas ketika masih dalam bentuk pelayanan monopoli oleh pos negara dimasa lalu.

d. Pemerintah yang Digerakkan oleh Misi : mengubah organisasi yang digerakkan oleh peraturan menjadi organisasi yang digerakkan oleh misi.

Mengenai apa yang dapat dan tidak dapat dilaksanakan oleh pemerintah daerah diatur dalam mandatnya. Namun tujuan pemerintah daerah bukanlah mandatnya, tetapi misinya.

e. Pemerintah yang Berorientasi Kepada Hasil: membiayai hasil, bukan masukan.

Pada pemerintahan daerah tradisional, besarnya alokasi anggaran pada suatu unit kerja ditentukan oleh kompleksitas masalah yang dihadapi (pemerintah daerah membiayai masukan). Semakin kompleks masalah yang dihadapi, semakin besar pula dana yang dialokasikan. Kebijakan seperti ini kelihatannya logis dan adil, akan tetapi yang terjadi adalah, unit kerja yang tidak punya inisiatif untuk memperbaiki kinerjanya. Akibatnya adalah justru, mereka beranggapan bahwa semakin lama suatu permasalah dapat dipecahkan, semakin besar peluangnya untuk memperoleh banyak anggaran. Pemerintah daerah berciri wirausaha berusaha merubah bentuk penghargaan dan bentuk insentif tersebut, mereka membiayai hasil dan bukan masukan. Pemerintah daerah yang berciri wirausaha mengembangkan suatu standar kinerja, yang akan mengukur seberapa baik suatu unit kerja mampu memecahkan permasalahan yang menjadi tanggungjawabnya. Semakin baik kinerjanya, semakin banyak pula dana yang akan dialokasikan untuk mengganti semua dana yang telah dikeluarkan oleh unit kerja tersebut.

f. Pemerintah Berorientasi pada Pelanggan: memenuhi kebutuhan pelanggan, bukan kebutuhan birokrasi.

Pemerintah daerah tradisional yang birokratis seringkali salah dalam mengidentifikasikan pelanggannya. Penerimaan pajak memang dari masyarakat dan dunia usaha, tetapi pemanfaataanya harus disetujui oleh 
DPRD. Akibatnya, pemerintah daerah seringkali menganggap DPRD dan semua pejabat yang ikut dalam pembahasan APBD adalah pelanggannya. Dalam kondisi seperti ini, pemerintah daerah tradisional akan memenuhi semua kebutuhan dan keinginan birokrasi, sedangkan pada masyarakat dan dunia bisnis yang merupakan pelanggan yang sesungguhnya bagi pemerintah malah sering diabaikan.

Pemerintah daerah yang berciri wirausaha akan mengidentifikasi para pelanggan yang sesungguhnya. Dengan cara seperti ini bukan berarti pemerintah akan mengabaikan DPRD, akan tetapi sebaliknya, ia menciptakan sistem pertanggungjawaban ganda (dual accountability); kepada DPRD dan kepada masyarakat luas dan dunia bisnis. Dengan demikian pemerintah daerah tidak akan arogan, tetapi secara terus menerus akan berupaya untuk lebih memuaskan masyarakat luas dan dunia bisnis.

g. Pemerintah Antisipatif: berupaya mencegah darpada mengobati

Pemerintah daerah tradisional yang birokratis memusatkan diri pada pelayanan public untuk memecahkan masalah public. Jenis pemerintahan yang birokratis tersebut biasanya cenderung bersikap reaktif. Seperti misalnya, Dinas Pemadam Kebakaran tidak bekerja apabila tidak ada kebakaran (masalah). Apabila tidak ada kebakaran maka tidak ada upaya pemecahan masalah berupa pencegahan agar tidak terjadi kebakaran.

Akan tetapi pemerintah daerah yang berciri wiwausaha tidak bersifat reaktif akan tetapi proaktif. Ia tidak hanya mencoba untuk mencegah masalah, akan tetapi juga berupaya keras untuk mengantisipasi masa depan. Ia menggunakan perencanaan strategis untuk menciptakan visi daerah. Visi daerah tersebut sangat membantu masyarakat luas, dunia bisnis, dan pemerintah daerah sendiri untuk meraih peluang yang tidak terduga serta menghadapi krisis yang tidak terduga pula, tanpa menunggu perintah.

h. Pemerintah Desentralisasi: dari hirarki menuju partisipatif dan tim kerja 
Lima puluh tahun yang lalu, pemerintah daerah yang sentralistis dan hirarkis sangat diperlukan. Pengambilan keputusan harus berasal dari pusat, mengikuti rantai komandonya hingga sampai pada staf yang paling berhubungan dengan masyarakat dan dunia bisnis. Pada saat tersebut sistim ini sangat cocok karena teknologi informasi masih sangat primitive, komunikasi antar berbagai lokasi masih lamban, dan staf pada pemrintah daerah masih relative belum terdidik (masih sangat membutuhkan petunjuk langsung terhadap apa yang harus dilaksanakan). Akan tetapi saat ini, keadaan sudah berubah, perkembangan teknologi sudah sangat maju, kebutuhan/keinginan masyarakat dan dunia bisnis sudah semakin kompleks, serta staf pemerintah daerah sudah banyak yang berpendidikan tinggi. Sekarang ini, pengambilan keputusan harus digeser ke tangan masyarakat, asosiasi-asosiasi, pelanggan, dan lembaga swadaya masyarakat.

i. Pemerintah Berorientasi pada (Mekanisme) Pasar: mengadakan perubahan dengan mekanisme pasar (system insentif) dan bukan bukan dengan mekanisme administratif (sistem prosedur dan pemaksaan).

Ada dua cara alokasi sumber daya, yaitu mekanisme pasar dan mekanisme administratif. Dari keduanya, mekanisme pasar terbukti sebagai yang terbaik dalam mengalokasikan sumber daya. Pemerintah daerah yang bercirikan birokrasi menggunakan mekanisme administrative, sedangkan pemerintah daerah yang bercirikan wirausaha menggunakan mekanisme pasar. Dalam mekanisme administrative, pemerintah daerah tradisional menggunakan perintah dan pengendalian, mengeluarkan prosedur dan definisi baku dan kemudian memerintahkan orang untuk melaksanakannya (sesuai dengan prosedur tersebut). dalam mekanisme pasar, pemerintah daerah wirausaha tidak memerintahkan dan mengawasi, tetapi mengembangkan dan menggunakansistem insentif agar orang tidak melakukan kegiatan-kegiatan yang merugikan masyarakat. 
$>$ Steering : Pengarah .

Rowing :

Pelaksana.

> Empowering:Pemberdayaan

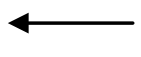

organisasi

Service:Pelayanan rutin.

pemerintah dan masyarakat.

$>$ Competition:Persaingan.

Monopoli: Tunggal.

$>$ Mission-driven:Mengarahkan

pata tugas

Role-

Driven:Berdasarkan

arahan/ petunjuk dari satu peraturan yang seragam.

$>$ Funding outcomes: inputs:

Menggunakan/melibatkan

Mengelola/menghabiskan

(Anggaran berdasarkan kinerja).

tersedia
Budgeting

dana

masyarakat

Anggaran yang

Dalam

satu

priode.

berimbang).

$>$ Customer driven: driven:

Penekanan pelayanan kepada pelanggan, pertanggungjawaban arah pertanggungjawaban kinerja pimpinan.

Arah kepada

\section{Bureaucracy-}

cepada 
diletakkan pada pelanggan.

Team work:

Bekerja sama dalam tim berdasarkan berdasarkan

keahlian dan kompetensi.

dalam

\section{Hierarchy:}

Kontrol

tingkatan

organisasi

Organization:

Pelayanan

pada organisasi

\section{Represif}

Mengobati

Mencegah

Mengobati

Konsep reinventing government muncul sebagai kritik atas kinerja pemerintah selama ini (pemerintahan yang berciri birokrasi), dan juga sekaligus sebagai antisipasi atas berbagai perubahan yang akan terjadi. Konsep ini menawarkan sepuluh prinsip dasar bagi sebuah model baru pemerintahan di masa yang akan datang. reinventing government memang merupakan konsep yang monumental, akan tetapi tanpa diikuti dengan perubahan-perubahan lain seperti bureaucracy reengineering, rightsizing, dan perbaikan mekanisme reward and punishment, maka konsep reinventing government tidak akan dapat mengatasi permasalahan birokrasi selama ini. Penerapan konsep reinventing government membutuhkan arah yang jelas dan political will yang kuat dari pemerintah dan dukungan masyarakat. Selain itu, yang terpenting adalah adanya perubahan pola piker dan mentalitas baru di tubuh birokrasi pemerintah itu sendiri oleh karena sebaik apapun konsep yang ditawarkan jika semangat dan mentalitas penyelenggara pemerintahan masih menggunakan paradigma lama, konsep tersebut hanya akan menjadi slogan kosong tanpa membawa perubahan apa-apa. 


\section{b. Good Governance}

Pengertian governance dapat diartikan sebagai cara mengelola urusanurusan publik. Word Bank memberikan definisi governance sebagai "the way state power is used in managing economic ang social resources for development of society". Sedangkan United Nation Development Program (UNDP) mendefinisikan governance sabagai "the evercise of political, economic and administrative authority to manage a nation's affair at all levels". Dalam hal ini, Word bank lebih menekankan pada cara pemerintah mengelola sumber daya social dan ekonomi untuk kepentingan pembangunan masyarakat, sedangkan UNDP lebih menkankan pada aspek politik, ekonomi, dan administrative dalam pengelolaan negara. Political governance mengacu pada pembuatan kebijakan (policy/strategy formulation), economic governance mengacu pada proses pembuatan keputusan di bidang ekonomi yang berimplikasi pada masalah pemerataan, penurunan kemiskinan, dan peningkatan kualitas hidup. Admionistrative governance mengacu pada system implementasi kebijakan.

Jika mengacu pada Word bank dan UNDP, orientasi pembangunan sector public adalah untuk menciptakan good governance. Pengertian good governance sering diartikan sebagai kepemerintahan yang baik. Sementara itu Word Bank mendefinisikan good governance sebagai suatu penyelenggaraan manajemen pembangunan yang solid dan bertanggung jawab yang sejalan dengan prinsip demokrasi dan pasar yang efisien, penghindaran salah alokasi dana investasi, dan pencegahan korupsi baik secara politik maupun secara administrative, menjalankan disiplin anggaran serta penciptaan legal and political frame work bagi tumbuhnya aktivitas usaha.

\section{Karakteristik Good Governance Menurut UNDP}

UNDP memberikan beberapa karakteristik pelaksanaan good governance yang meliputi :

1. Participation, keterlibatan masyarakat dalam pembuatan keputusan baik secara langsung maupun tidak langsung melalui lembaga perwakilan yang 
dapat menyalurkan aspirasinya. Partisipasi tersebut dibangun atas dasar kebebasan berasosiasi dan berbicara serta berpartisipasi secara konstruktif.

2. Rule of Law, kerangka hokum yang adil dan dilaksanakan tanpa pandang bulu.

3. Transparency, transparansi dibangun atas dasar kebebasan memperoleh informasi. Informasi yang berkaitan dengan kepentingan public secara langsung dapat diperoleh oleh mereka yang membutuhkan.

4. Responsiveness, lembaga-lembaga public harus cepat dan tanggap dalam melayani stake holders.

5. Concensus Orientation, berorientasi pada kepentingan masyarakat yang lebih luas.

6. Equity, setiap masyarakat memiliki kesempatan yang sama untuk memperoleh kesejahteraan dan keadilan.

7. Efficiency and effectiveness, pengelolaan sumber daya public dilakukan secara berdaya guna (efisien) dan berhasil guna (efektif).

8. Accountability, pertanggunjawaban kepada public atas setiap aktivitas yang dilakukan.

9. Strategic Vision, penyelenggara pemerintahan dan masyarakat harus memiliki visi jauh ke depan. 


\section{BAB V \\ PARTAI POLITIK DAN KELOMPOK KEPENTINGAN}

\section{PARTAI POLITIK}

\section{Pengertian Partai Politik}

Carl friedrich dalam (Surbakti : 1999 : 116), memberi batasan mengenai partai politik, yaitu sekelompok manusia yang terorganisasikan secara stabil dengan tujuan untuk merebut atau mempertahankan kekuasaan dalam pemerintahan bagi pemimpin partainya, dan berdasarkan kekuasaan itu akan memberikan kegunaan materil dan idiil kepada para anggotanya. Sementara itu, Soltau dalam (Surbakti : 1999 : 116), juga memberikan definisi partai politik sebagai kelompok warga negara yang sedikit banyak terorganisasikan, yang bertindak sebagai suatu kesatuan politik dan dengan memanfaatkan kekuasaannya untuk memilih, bertujuan untuk menguasai pemerintahan dan menjalankan kebijakan umum yang mereka buat.

Dari uraian tersebut di atas dapat kita rumuskan pengertian partai politik merupakan kelompok anggota yang terorganisasi secara rapi dan stabil yang dipersatukan dan dimotivasi dengan ideologi tertentu, dan yang berusaha mencari dan mempertahankan kekuasaan dalam pemerintahan melalui pemilihan umum guna melaksanakan alternatif kebijakan umum yang mereka susun. Alternatif kebijakan umum yang disusun ini merupakan hasil pemaduan berbagai kepentingan yang hidup dalam masyarakat, sedangkan cara mencari dan mempertahankan kekuasaan guna melaksanakan kebijakan umum dapat melalui pemilihan umum dan cara-cara lain yang sah

\section{Fungsi Partai Politik}

Fungsi utama partai politik ialah mencari dan mempertahankan kekuasaan guna mewujudkan program-program yang disusun berdasarkan ideologi tertentu. Cara yang digunakan oleh suatu pertai politik dalam sistem politik demokrasi untuk mendapatkan dan mempertahankan kekuasaan ialah 
ikut serta dalam pemilihan umum, sedangkan cara yang digunakan partai tunggal dalam sistem politik totaliter berupa paksaan fisik dan psikologik oleh suatau diktatorial kelompok (komunis) maupun oleh diktatorial individu (fasis).

Ketika melaksanakan fungsi itu partai politik dalam sistem politik demokrasi melakukan tiga kegiatan. Adapun ketiga kegiatan meliputi seleksi calon-calon, kampanye, dan melaksanakan fungsi pemerintahan (legislatif dan / atau eksekutif). Apabila kekuasaan untuk memerintah telah diperoleh maka partai politik itu berperan pula sebagai pembuat keputusan politik. Partai politik yang tidak mencapai mayoritas di badan perwakilan rakyat akan berperan sebagai pengontrol terhadap partai mayoritas. Dalam sistem politik totaliter kalaupun dilaksanakan maka pemilihan umum lebih berfungsi sebagai sarana pengesahan calon tunggal yang telah ditetapkan lebih dahulu oleh partai tunggal. Namun, partai politik baik dalam sistem politik demokrasi maupun dalam sistem politik totaliter, juga melaksanakan sejumlah fungsi lain. Berikut ini dikemukakan sejumlah fungsi lain tersebut.

\section{a. Sosialisasi Politik}

Yang dimaksud dengan sosialisasi politik adalah proses pembentukan sikap dan orientasi politik para anggota masyarakat. Melalui proses sosialisasi politik inilah para anggota masyarakat memperoleh sikap dan orientasi terhadap kehidupan politik yang berlangsung dalam masyarakat. Proses ini berlangsung seumur hidup yang diperoleh secara sengaja melalui pendidikan formal, nonformal dan informal maupun secara tidak sengaja malalui kontak dan pengalaman sehari-hari baik dalam kehidupan keluarga dan tetangga maupun dalam kehidupan masyarakat.

Dari segi metode penyampaian pesan, sosialisasi politik dibagi dua, yakni : pendidikan politik dan indoktrinasi politik.

1. Pendidikan politik merupakan suatu proses dialogis di antara pemberi dan penerima pesan. Melalui proses ini, para anggota 
masyarakat mengenal dan mempelajari nilai-nilai, norma-norma, dan simbol-simbol politik negaranya dari berbagai pihak dalam sistem politik seperti sekolah, pemerintah, dan partai politik. Pendidikan politik dipandang sebagai proses dialog antara pendidik seperti sekolah, pemerintah, partai politik dan peserta didik dalam rangka pemahaman, penghayatan dan pemahaman nilai, norma dan simbol politik yang dianggap ideal dan baik. Melalui kegiatan kursus, latihan kepemimpinan, diskusi dan keikutsertaan dalam berbagai forum pertemuan, partai politik dalam sistem politik demokrasi dapat melaksanakan fungsi pendidikan politik.

2. Indoktrinasi politik ialah proses sepihak ketika penguasa memobilisasi dan memanipulasi warga masyarakat untuk menerima nilai, norma, dan simbol yang dianggap oleh pihak yang berkuasa sebagai ideal dan baik. Indoktrinasi politik ini dilakukan melalui berbagai forum pengarahan yang penuh dengan paksaan psikologis, dan latihan yang penuh disiplin.

\section{b. Rekrutmen Politik.}

Rekrutmen politik ialah seleksi dan pemilihan atau seleksi dan pengangkatan seseorang atau sekelompok orang untuk melaksanakan sejumlah peranan dalam sistem politik pada umumnya dan pemerintahan pada khususnya. Fungsi ini semakin besar porsinya manakala partai politik itu merupakan partai tunggal seperti dalam sistem politik totaliter, atau manakala suatu partai merupakan mayoritas di dalam badan perwakilan rakyat sehingga berwenang membentuk pemerintahan dalam sistem politik demokrasi. Fungsi rekrutmen merupakan kelanjutan dari fungsi mencari dan mempertahankan kekuasaan. Selain itu, fungsi rekrutmen politik sangat penting bagi kelangsungan sistem politik sebab tanpa elit yang mampu 
melaksanakan peranannya, kelangsungan hidup suatu sistem politik akan terancam berakhir.

\section{c. Partisipasi Politik}

Partisipasi politik ialah kegiatan warga negara biasa dalam mempengaruhi proses pembuatan dan pelaksanaan kebijaksanaan umum dan ikut menentukan pemimpin pemerintahan. Kegiatan yang dimaksud antara lain mengajukan tuntutan, membayar pajak, melaksanakan keputusan, mengajukan kritik dan koreksi atas pelaksanaan suatu kebijakan umum, dan mendukung atau menentang calon pemimpin tertentu, mengajukan alternatif pemimpin, dan memilih wakil rakyat dalam pemimlihan umum. Dalam hal ini, partai politik mempunyai fungsi untuk membuka kesempatan, mendorong, dan mengajak para anggota dan anggota masyarakat yang lain untuk menggunakan partai politik sebagai saluran kegiatan mempengaruhi proses politik. Fungsi ini lebih tinggi porsinya dalam sistem politik demokrasi daripada dalam sistem politik totaliter karena dalam sistem politik yang terakhir ini lebih mengharapkan ketaatan dari para warga negara.

\section{d. Pemadu Kepentingan}

Dalam masyarakat terdapat sejumlah kepentingan yang berbeda bahkan kadang kala saling bertentangan seperti antara kehendak mendapatkan keuntungan sebanyak-banyaknya dan kehendak untuk mendapatkan barang dan jasa dengan harga murah tapi bermutu; antara kehendak untuk mencapai efisiensi dan penerapan teknologi yang canggih tetapi memerlukan tenaga kerja yang sedikit, dan kehendak untuk mendapatkan dan mempertahankan pekerjaan; antara kehendak untuk mencapai dan mempertahankan mutu pendidikan tinggi dengan jumlah penerimaan mahasisiwa yang lebih sedikit, dan kehendak masyarakat untuk menyekolahkan anak ke perguruan tinggi; antara kehendak menciptakan dan memelihara kestabilan politik dan kehendak berbagai kelompok seperti 
mahasiswa, intelektual, pers, dan kelompok agama untuk berkumpul dan menyatakan pendapat secara bebas.

Untuk menampung dan memadukan berbagai kepentingan yang berbeda dan bahkan sering bertentangan itu maka partai politik dibentuk. Menurut Almond dan Powel dalam (Surbakti :1999 : 119), yang dimaksud dengan fungsi pemadu kepentingan adalah kegiatan menampung , menganalisis dan memadukan berbagai kepentingan yang berbeda menjadi berbagai alternatif kepentingan umum, kemudian diperjuangkan dalam proses pembuatan dan pelaksanaan keputusan politik.

Sebagaimana dikemukakan di atas, fungsi ini merupakan salah satu fungsi utama partai politik sebelum mencari dan mempertahankan kekuasaan. Fungsi ini sangat menonjol dalam sistem politik demokrasi. Karena dalam sistem politik totaliter, kepentingan dianggap seragam maka partai politik dalam sistem ini kurang melaksanakan fungsi pemaduan kepentingan. Alternatif kebijakan umum yang diperjuangkan oleh partai tunggal dalam sistem politik totaliter lebih banyak merupakan tafsiran atas ideologi doktriner. Dalam sistem politik demokrasi, ideologi digunakan sebagai cara memandang permasalahan dan perumusan penyelesaian permasalahan.

\section{e. Komunikasi Politik}

Pendapat Lucyan W. Pie dalam (Surbakti :1999 : 119), bahwa komunikasi politik adalah proses penyampaian informasi mengenai politik dari pemerintah kepada masyarakat dan dari masyarakat kepada pemerintah. Dalam hal ini, partai politik berfungsi sebagai komunikator politik yang tidak hanya menyampaikan segala keputusan dan penjelasan pemerintah kepada masyarakat sebagaimana diperankan oleh partai politik di negara totaliter tetapi juga menyampaikan aspirasi dan kepentingan berbagai kelompok masyarakat kepada pemerintah. Kedua fungsi ini dilaksanakan oleh partaipartai politik dalam sistem politik demokrasi. 
Dalam melaksanakan fungsi ini partai politik tidak menyampaikan begitu saja segala informasi dari pemerintah kepada masyarakat atau dari masyarakat kepada pemerintah, tetapi merumuskannya sedemikian rupa sehingga penerima informasi (komunikan) dapat dengan mudah memahami dan memanfaatkan. Dengan demikian segala kebijakan pemerintah yang biasanya tidak terumuskan dalam bahasa teknis diterjemahkan ke dalam bahasa yang mudah dipahami masyarakat. Sebaliknya, segala aspirasi, keluhan dan tuntutan masyarakat yang biasanya tidak terumuskan dalam bahasa teknis dapat diterjemahkan oleh partai politik ke dalam bahasa yang dapat dipahami oleh pemerintah. Jadi, proses komunikasi politik antara pem,erintah dan masyarakat dapat berlangsung secara efektif melalui partai politik.

\section{f. Pengendalian Konflik}

Konflik yang dimaksud di sini dalam arti yang luas, mulai dari perbedaan pendapat sampai pada pertikaian fisik antara individu atau kelompok dalam masyarakat. Dalam negara demokrasi, setiap warga negara atau kelompok masyarakat berhak menyampaikan dan memperjuangkan aspirasi dan kepentingannya sehingga konflik merupakan gejala yang sukar dielakkan.

Akan tetapi, tentu suatu sistem politik hanya akan mentolerir konflik

yang tidak menghancurkan dirinya sehingga permasalahanya bukan menghilangkan konflik itu, melainkan mengendalikan konflik melalui lembaga demokrasi untuk mendapatkan penyelesaian dalam bentuk keputusan politik.

Partai politik sebagai salah satu lembaga demokrasi berfungsi untuk mengendalikan konflik melalui cara berdialog dengan pihak-pihak yang berkonflik, menampung dan memadukan berbagai aspirasi dan kepentingan dari pihak-pihak yang berkonflik dan membawa permasalahan ke dalam musyawarah badan perwakilan rakyat untuk mendapatkan penyelesaian berupa keputusan politik. Untuk mencapai penyelesaian berupa keputusan itu 
diperlukan kesediaan berkompromi di antara para wakil rakyat yang berasal dari partai-partai politik. Apabila partai-partai politik keberatan untuk mengadakan kompromi maka partai politik bukannya mengendalikan konflik, melainkan menciptakan konflik dalam masyarakat.

\section{g. Kontrol Politik}

Kontrol politik ialah kegiatan untuk menunjukkan kesalahan dan penyimpangan dalam isi suatu kebijakan atau dalam pelaksanakan kebijakan yang dibuat dan dilaksanakan oleh pemerintah. Dalam melakukan suatu kontrol politik atau pengawasan harus ada tolok ukur yang jelas sehingga kegiatan itu bersifat relatif objektif.

Tolok ukur suatu kontrol politik berupa nilai-nilai politik yang dianggap ideal dan baik (ideologi) yang dijabarkan ke dalam berbagai kebijakan atau peraturan perundang-undangan. Tujuan kontrol politik, yakni meluruskan kebijakan atau pelaksanaan kebijakan yang menyimpang dan memperbaiki yang keliru sehingga kebijakan dan pelaksanaannya sejalan dengan tolok ukur tersebut. fungsi kontrol ini merupakan salah satu mekanisme politik dalam sistem politik demokrasi untuk memperbaiki dan memperbaharui dirinya secara terus menerus.

Dalam melaksanakan fungsi kontrol politik, partai politik juga harus menggunakan juga tolok ukur tersebut sebab tolok ukur itu pada dasarnya merupakan hasil kesepakatan bersama sehingga seharusnya menjadi pegangan bersama. Dalam sistem kabinet parlementer, kontrol yang dilakukan oleh partai politik oposisi terhadap kebijakan partai yang memerintah dapat menjatuhkan partai yang berkuasa apabila mosi tidak percaya (karena pemerintah sulit memberi penjelasan yang memuaskan terhadap isi kontrol politik oposisi) mendapatkan dukungan mayoritas dari parlemen.

Menurut Samuel P. Huntington dalam (Surbakti : 1999 : 121), bahwa berdasarkan kenyataan tidak semua fungsi dilaksanakan dalam porsi dan 
tingkat keberhasilan yang sama. Hal ini tidak hanya bergantung pada sistem politik yang menjadi konteks yang melingkupi partai politik, tetapi juga ditentukan oleh faktor lain. Di antara faktor lain itu berupa tingkat dukungan yang diberikan anggota masyarakat terhadap partai politik (berakar tidaknya partai dalam masyarakat), dan tingkat kelembagaan partai yang dapat diukur dari segi kemampuan adaptasi, kompleksitas organisasi, otonomi, dan kesatuannya.

\section{KELOMPOK KEPENTINGAN}

Kelompok kepentingan ialah sarana yang digunakan sekelompok orang yang memiliki kepentingan yang sama dan secara bersama-sama menyampaikan kepentingan mereka kepada pemerintah. Kepentingan tersebut dapat berupa kebutuhan-kebutuhan, keinginan-keinginan, nilai-nilai, dan harapan-harapan - yang bisa terpenuhi, akan tetapi bisa juga dikecewakan oleh tindakan-tindakan pemerintah. Seseorang ataupun sekelompok orang bisa pula diuntungkan akan tetapi bisa dirugikan oleh tindakan atau keputusan tersebut. Oleh karena itu warga negara sangat memperhatikan dan berkepentingan dengan keputusan-keputusan yang dibuat oleh pemerintah. Mereka menyatakan atau mengartikulasikan kepentingan mereka kepada lembaga-lembaga politik dan pemerintah melalui kelompok-kelompok yang mereka bentuk bersama dengan orang lain yang memiliki kepentingan yang sama.

Walaupun kelompok kepentingan yang terorganisir tidak mudah dibedakan dengan partai politik, akan tetapi ada satu perbedaan yang nampaknya secara umum diterima. Suatu kelompok kepentingan adalah setiap organisasi yang berusaha mempengaruhi kebijaksanaan pemerintah, dan pada waktu yang sama tidak berkeinginan memperoleh jabatan publik. Sebalikanya, partai politik benar-benar bertujuan untuk menguasai jabatanjabatan publik, yaitu jabatan politik, maupun jabatan pemerintahan. 
Dalam praktek, perbedaan tersebut tidak setegas itu. Keanggotaan kelompok kepentingan dan keanggotaan partai politik sering tumpang tindih, dan lebih-lebih lagi, kelompok kepentingan sering terlibat dalam penyeleksian calon-calon keanggotaan partai politik dan selalu berusaha agar anggotaanggotanya terwakili dalam komisi-komisi yang dibentuk oleh pemerintah. Kadang-kadang pula kelompok kepentingan bahkan berkembang menjadi partai politik.

\section{A. Jenis-jenis Kelompok Kepentingan}

Sebagaimana dikatakan oleh Gabriel A. Almond dalam (Mas'oed dan MacAndrews : 2000 : 53), bahwa kelompok-kelompok kepentingan berbedabeda dalam struktur, gaya, sumber pembiayaan, dan basis dukungannya. Perbedaan tersebut sangat besar pengaruhnya dalam kehidupan politik, ekonomi, dan sosial suatu bangsa. Walaupun kelompok-kelompok kepentingan juga diorganisir berdasar keanggotaan, kesukuan, ras, etnis, agama, ataupun berdasarkan isu-isu kebijaksanaan - kelompok kepentingan yang paling kuat, paling besar, dan secara finansial paling mampu adalah kelompok yang berdasarkan pada bidang pekerjaan atau profesi. Berikut ini adalah beberapa jenis kelompok kepentingan yang dikenal, diantaranya adalah :

\section{Kelompok Anomik}

Kelompok-kelompok anomik ini terbentuk secara spontan dan seketika, dan tidak memiliki nilai-nilai, norma-norma yang mengatur serta tidak terorganisir. Jenis kelompok ini terbentuk tanpa ada yang merencanakan sebelumnya, terjadi begitu saja, yang mungkin penyebabnya adalah ketidakpuasan yang lama menumpuk dan dilampiaskan seketika pada saat ada pemicu dan bubar dengan sendirinya. Jenis kelompok ini sering bertumpang tindih (overlap) dengan bentuk-bentuk partisipasi politik nonkonvensional seperti demonstrasi, kerusuhan, tindak kekerasan politik dan sebagainya. Sehingga apa yang dianggap sebagai perilaku anomik mungkin 
saja tidak lebih dari tindakan-tindakan kelompok terorganisir (bukan kelompok anomik) yang menggunakan cara-cara nonkonvensional seperti kekerasan. Boleh jadi kelompok terorganisir yang oleh karena kepentingannya tidak terwakili secara memadai dalam sistem politik, melakukan suatu insiden yang sepintas lalu terkesan terjadi secara spontan dan mengarah kepada ledakan yang tidak dapat dikendalikan lagi, bila salah memahami hakikat kejadian tersebut lalu menganggapnya sebagai tindakan kelompok anomik. Kita harus hati-hati menilai, sebab sering kali yang nampak anomik itu kadang kala merupakan tindakan yang direncanakan secara teliti oleh kelompok kepentingan yang terorganisir.

\section{Kolompok Non-Assosiasional}

Kelompok kepentingan non-assosiasional pada dasarnya sudah terorganisasi, akan tetapi jarang yang terorganisir dengan rapi dan kegiatannya bersifat temporer. Kelompok ini berwujud seperti kelompokkelompok keluarga dan keturunan atau etnik, regional, status dan kelas yang menyatakan kepentingan secara kadangkala melalui individu-individu, klikklik, kepala keluarga, atau pemimpin agama.

Secara teoretis, kegiatan kelompok non-assosiasional terutama sekali merupakan ciri masyarakat belum maju, di mana kesetiaan kesukuan atau keluarga-keluarga bangsawan mendominasi kehidupan politik. Akan tetapi dalam negara industri majupun, kelompok non-assosiasional seperti keluargakeluarga yang masih berpengaruh, tokoh-tokoh kedaerahan, serta pemimpinpemimpin agama seringkali menerapkan pengaruhnya yang seringkali lebih besar dari pengaruh kelompok professional. Sarana yang sering digunakan jenis kelompok ini untuk mempengaruhi pemerintah biasanya pertemuanpertemuan informal yang sering dihadiri oleh pejabat pemerintah maupun pimpinan partai. 


\section{Kelompok Institusional}

Organisasi-organisasi seperti partai politik, perusahaan besar, badan legilatif, militer, birokrasi, dianggap sebagai kelompok kepentingan institusional atau memiliki anggota-anggota yang khusus bertanggungjawab melakukan kegiatan lobbying. Kelompok ini bersifat formal dan memiliki fungsi-fungsi politik atau sosial lain selain fungsi artikulasi kepentingan.

Bila kelompok-kelompok kepentingan institusional sangat besar pengaruhnya, hal ini disebabkan oleh basis organisasinya yang kuat. Jenis kelompok kepentingan ini sangat dominan pengaruhnya di negara-negara maju, jika dibandingkan dengan jenis kelompok non-assosiasional.

\section{Kelompok Assosiasional}

Kelompok assosiasional seperti serikat buruh, kamar dagang, atau perkumpulan pengusahan dan industri (seperti di indonesia : Kadin, Gapensi, Inkindo, dan lain-lain), paguyuban etnik, persatuan kelompok keagamaan, dan sebagainya. Secara khas kelompok ini menyatakan kepentingan dengan cara memakai tenaga staf professional serta memiliki prosedur standar untuk merumuskan kepentingan.

Kelompok kepentingan ini sangat besar pengaruhnya dalam membela kepentingan mereka. Kegiatan utama mereka adalah melakukan tawarmenawar (bargaining) di luar saluran-saluran partai politik dengan pejabatpejabat pemerintah tentang kebijakan yang akan diambil oleh pemerintah, atau usul suatu rancangan undang-undang di parlemen. Kelompok ini juga berusaha mempengaruhi pendapat umum (public opinion) dengan cara kampanye-kampanye lewat iklan.

Studi-studi menunjukkan bahwa kelompok kepentingan assosiasional bila diizinkan berkembang cenderung untuk menentukan perkembangan dari jenis-jenis kelompok kepentingan yang lain. Basis organisasi yang menempatkannya berada di atas kelompok kepenetingan non-assosiasional, taktik dan tujuannya sering diakui sah dalam masyarakat. Dan dengan 
mewakili kelompok dan kepentingan yang luas, kelompok assosiasional dengan efektif bisa membatasi pengaruh anomik, non-assosiasional, dan institusional.

\section{B. BAGAIMANA MENCAPAI KAUM BERPENGARUH}

Agar efektif, kelompok kepentingan harus mempu mencapai atau berhubungan langsung dengan pembuat keputusan politik utama. Kelompok kepentingan dapat saja menyatakan kepentingan anggotanya secara informal maupun formal. Tetapi tanpa mampu menyusupi atau mempengaruhi struktur pembuatan keputusan politik mereka tidak akan berhasil. Kelompokkeleompok kepentingan ini memiliki strategi yang berbeda-beda untuk untuk mencapai kaum berpengaruh, dan cara mereka mengorganisir pengaruh berbeda-beda di masing-masing sistem politik.

Misalnya, bila hanya ada satu saluran utama yang sah untuk mencapai kaum berpengaruh - seperti dalam sistem politik yang didominasi oleh satu partai tunggal dan totaliter - sangat sulit bagi semua kelompok umtuk secara efektif berhubungan langsung dengan kaum berpengaruh tersebut. tuntutantuntutan yang disalurkan melalui saluran yang tunggal tersebut bisa jadi diselewengkan sebelum mencapai para pembuat keputusan utama. Dengan demikian para pembuat keputusan dihalangi dalam memperoleh informasi tentang kebutuhan dan tuntutan dari kelompok-kelompok kepentingan dalam masyarakat. Dalam jangka panjang, hal ini dengan mudah dapat membuat para pengambil keputusan tersebut salah perhitungan dan dapat menimbulkan keresahan dari kelompok-kelompok yang tidak puas yang dapat menimbulkan kerusuhan.

Dalam mengkomunikasikan tuntutan politik, individu-individu yang mewakili kelompok kepentingan atau dirinya sendiri biasanya tidak hanya ingin sekadar memberi informasi. Mereka bertujuan agar pandanganpandangan mereka dipahami oleh para pembuat keputusan yang relevan dengan kepentingan mereka, dan memperoleh tanggapan baik. Karena itulah 
kelompok kepentingan berusaha mencari saluran-saluran khusus untuk menyalurkan tuntutan mereka dan mengembangkan teknik-teknik penyampaian pesan agar tuntutan itu diperhatikan dan ditanggapi. Dan saluran-saluran untuk menyatakan pendapat dalam mesayarakat berpengaruh besar dalam menentukan luas dan efektifnya tuntutan kelompok kepentingan. Saluran-saluran paling penting adalah sebagai berikut.

\section{Demonstrasi dan Tindakan Kekerasan}

Salah satu sarana untuk menyatakan tuntutan adalah melalui demonstrasi dan tindak kekerasan fisik. Seperi telah kita sebut di muka, kerusuhan, demonstrasi, dan pembunuhan merupakan ciri khas kelompok kepentingan anomik, tetapi sering juga kelompok kepentingan lain menggunakan sarana ini : karena itu perlu dibedakan antara (1) tindakan kekerasan spontan oleh kelompok kepentingan anomik ; dengan (2) tindak kekerasan dan demonstrasi sebagai sarana menyatukan tuntutan yang bisa dipakai oleh kelompok kepentingan yang lain.

\section{Hubungan Pribadi}

Sarana kedua untuk mencapai elit politik adalah melalui hubungan pribadi - misalnya dengan menggunakan keluarga, sekolah, hubunganhubungan kedaerahan sebagai perantara.

Walaupun hubungan pribadi ini umumnya dipergunakan kelompok nonassosiasional yang mewakili kepentingan keluarga atau daerah, tetapi sering juga digunakan oleh kelompok assosiasional dan kelompok kepentingan lain. Hal ini terjadi di semua sistem politik, baik yang tradisional mapun yang modern. Hubungan langsung melalui tatap muka merupakan salah satu cara paling efektif dalam membentuk sikap seseorang. Bila hubungan ini terjadi dalam suasana yang ramah tamah dan bersahabat, besar kemungkinan akan memperoleh tanggapan baik. Tuntutan yang disampaikan oleh seorang teman, 
anggota keluarga, atau tetangga baik, lebih banyak diperhatikan daripada bila disampaikan secara formal oleh orang yang belum dikenal.

\section{Perwakilan Langsung}

Perwakilan atau representasi langsung dalam badan legislatif dan birokrasi memungkinkan suatu kelompok kepentingan untuk mengkomunikasikan secara langsung dan kontinyu kepentingankepentingannya melalui seorang anggota aktif dalam struktur pembuat keputusan. Anggota kelompok kepentingan institusional pemerintahan sering mempunyai hubungan sehari-hari dengan para pembuat keputusan, dan biasanya anggota-anggotanya sendiri terlibat dalam pembuatan keputusan dalam suatu depertemen ataukah bagian pemerintahan tempat mereka beraktivitas.

\section{Saluran Formal dan institusional lain}

Saluran-saluran lain tersebut yang harus diperhatikan salah satunya adalah media massa seperti surat kabar, radio, televisi, dan majalah. Akan tetapi bila media massa itu dikendalikan atau disensor oleh elit politik penguasa, maka fungsinya jadi merosot, atau hanya menyalurkan kepentingan kelompok yang disukai oleh penguasa saja. Dalam masyarakat terbuka media massa merupakan penyalur utama tuntutan politik dan sarana mencapai pembuatan keputusan.

Saluran institusional penting kedua adalah partai politik. Tetapi ada beberapa faktor yang mempengaruhi efektifitasnya. Partai yang sangat ideologis dengan struktur oreganisasinya berbentuk hirarki seperti partai komunis, lebih cenderung untuk mengendalikan kelompok-kelompok 
kepentingan yang berafiliasi dengannya dan kurang mengkomunikasikan tuntutan-tuntutan dari kelompok-kelompok tersebut.

Saluran institusional ketiga adalah melalui badan legislatif, kabinet, maupun birokrasi. Dengan menggunakan strategi lobbying suatu tuntutan atau informasi dapat disampaikan melalui pernyataan di depan anggota parlemen, pejabat pemerintah, dan pejabat birokrasi yang lainnya. Hubungan dengan birokrasi di berbagai tingkatan dan depertemen sangat penting terutama bila wewenang pembuatan keputusan didelegasikan ke bawah.

\section{Efektivitas Kelompok Kepentingan}

Faktor-faktor yang menentukan efektivitas kelompok kepentingan antara lain adalah kemampuan untuk mengerahkan dukungan, tenaga, dan sumber daya dari anggota-anggotanya. Begitu pula luas sumber daya yang dimiliki seperti kemampuan finansial, jumlah anggota, kecakapan politik, kesatuan organisasi dan prestisenya di mata masyarakat dan pemerintah.

Di samping sifat internalnya tersebut, efektivitas kelompok kepentingan juga dipengaruhi oleh sifat dari isu dan kebijakan pemerintah yang terjadi saat itu. Misalnya, pada suatu saat kebijakan pemerintah menekankan pada pengembangan industri yang berskala besar, maka yang punya peluang lebih besar untuk memiliki pengaruh adalah kelompok-kelompok kepentingan yang memiliki anggota dengan pengetahuan yang luas dan kepentingan khusus dalam bidang industri. Akan tetapi bila arah kebijakan pemerintah beralih kepada pembangunan sosial, maka kelompok-kelompok kepentingan yang mengkhususkan diri dalam perencanaan kota, perumahan, transportasi, pengobatan, dan kesejahteraan sosial akan memperoleh lebih banyak pengaruh.

Efektifitas kelompok kepentingan sebagian besar juga ditentukan oleh perbedaan-perbedaan struktur pemerintahan, seperti federal, kesatuan. Begitu pula otonomi dan kebebasan kelompok kepentingan juga merupakan 
faktor penting yang dapat mempengaruhi efektivitas kelompok kepentingan tersebut. 


\section{DAFTAR PUSTAKA}

Afan Gaffar (editor). 1983. Beberapa Aspek Pembangunan Politik. CV. Rajawali : Jakarta.

David Osborne dan Ted Gaebler. 1999. Mewirausakan Birokrasi : Mentransformasi Semangat Wirausaha ke Dalam Sektor Publik. PPM : Jakarta

David Osborne dan Peter Plastrik. 2000. Memangkas Birokrasi : Lima Strategi Menuju Pemerintahan Wirausaha. PPM : Jakarta.

Isjwara. 1999. Pengantar Ilmu Politik. Putra A. Bardin : Bandung.

Mardiasmo. 2004. Otonomi dan Manajemen Keuangan Daerah. Andi : Yogyakarta.

Mohtar Mas'oed dan Colin MacAndrews. 2000. Perbandingan Sistem Politik. Gajah Mada University Press : Yogyakarta.

Ramlan Surbakti. 1999. Memahami Ilmu Politik. PT. Gramedia : Jakarta.

Sri Jutmini dan Winarno. 2007. Pendidikan Kewarganegaraan. PT. Tiga Serangkai Pustaka Mandiri : Solo. 